\title{
Bakir Bir Araştırma Sahası Olarak Osmanlı Tercüme Geleneği*
}

\section{The Ottoman Translation Tradition as an Untouched Field of Research}

\section{Sadık $\operatorname{Yazar}^{1}[\mathbb{C}$}

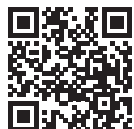

*Bu makale, temelde 11-13 Kasım 2011 tarihlerinde düzenlenen Türk Dili ve Edebiyatının Sorunları ve Cözümleri (TUDES) başlıklı konferansta sunulan "Tercüme Metinleri Üzerine" başlıklı sunumun önemli oranda geliştirilmiş şeklidir.

'Prof. Dr., İstanbul Medeniyet Üniversitesi, Edebiyat Fakültesi, Türk Dili ve Edebiyatı Bölümü, İstanbul, Türkiye

ORCID: S.Y. 0000-0001-8029-5723

Sorumlu yazar/Corresponding author: Sadık Yazar,

İstanbul Medeniyet Üniversitesi Edebiyat Fakültesi, Türk Dili ve Edebiyatı Bölümü, İstanbul, Türkiye

E-mail: zyazar@gmail.com

Başvuru/Submitted: 08.06.2020

Kabul/Accepted: 10.06 .2020

\section{Atıf/Citation:}

Yazar, S. (2020). Bakir bir araștırma sahası olarak Osmanlı tercüme geleneği.TUDED 60(1), 153-178. https://doi.org/10.26650/TUDED2020-0042

\section{ÖZET}

Türkiye'de çeviri etkinliklerine yönelik yapılan araştırma ve incelemeler, özellikle 2000'li y1llardan sonra artarak devam etmektedir; farklı disiplinlere mensup araştırmacılar tarafından gerçekleștirilen bu araştırmaların büyük bir bölümü Cumhuriyet dönemindeki çevirilere, az bir kısmı da Tanzimat sonrası Batı kaynaklı çevirilere odaklanmaktadır. XIII. yüzyıldan başlayarak Cumhuriyet dönemine kadarki uzun dönemde, kaynağını büyük oranda İslam medeniyetinde Arapça ve Farsça ile yazılan eserlerin oluşturduğu Türkçe tercüme geleneği ise yeteri kadar ilgiyi çekmemiştir. Zehra Toska ve Saliha Paker gibi araştırmacıların davetlerinden sonra, Osmanlı çeviri tarihi araştırmalarına yönelik yeni bir davet olması beklenen bu makalenin birinci kısmında; Osmanlı tercüme tarihine yönelik şu ana kadar yapılan araştırmalar, bilimsel disiplinlere göre sınıflandırılıp bazı temsilci çalışmalar zikredilerek betimlenmeye çalışılacaktır. Bu bölümü müteakiben Osmanlı tercüme geleneğinin araştırma ve incelemeye açık alanlarına işaret edilip konuyla ilgili bazı araștırma soruları sıralanacaktır. Böylece çeviribilimin alanını genișletip çeșitlendirecek, Türkoloji sahasında ise bu türden tercüme metinlerine yönelik daha nitelikli araștırma ve incelemelerin oluşmasını sağlayacak șekilde Osmanlı tercüme geleneğinin bakir bir alan olarak araştırmacıları beklediği vurgulanmaya çalıșılacaktır. Makalenin sonuç kısmında ise Osmanlı çeviri tarihçisinin sahip olması beklenen asgari düzeydeki yeterlikleri üzerinde durulacaktır.

Anahtar Kelimeler: Tercüme (Çeviri), Osmanlı tercüme geleneği, tercüme (çeviri) tarihi, çeviribilim, klasik Türk edebiyatı

\section{ABSTRACT}

Studies on translation activities in Turkey continue to increase in number, especially after the 2000s. Most of this research focuses on the Republican era, while a few focus on translations based on Western sources after the Tanzimat. In the long period from the thirteenth century to the Republican era, the Turkish translation tradition, whose sources in Islamic civilization were largely written in Arabic and Persian, did not attract much attention. In the first part of this article, which is intended to be a new invitation to researchers of Ottoman translation history, the previous studies on Ottoman translation history are arranged according to scientific disciplines, and we attempt to describe them by mentioning some representative studies. Following this section, some research questions related to the topic are listed, highlighting the areas of the Ottoman translation tradition that are open for fruitful research and investigation. It is emphasized that the Ottoman translation tradition is available to researchers as a untouched field, in such a way that it will expand and diversify the field of Translation Studies and it will be possible, going forward, to conduct more qualified research and studies on such translation texts in the field of Turkology. The last part of the article mentions the minimum level of qualifications expected of a historian of Ottoman translation.

Keywords: Translation, history of the Ottoman translation, history of translation, translation studies, classical Turkish literature 


\section{EXTENDED ABSTRACT}

Research and studies carried out on translation activities in Turkey continue to increase in number, especially after the 2000s. Most of these studies focus on the Republican era, while a few of them focus on translations based on Western sources after the Tanzimat. In the long period from the thirteenth century to the Republican era, the Turkish translation tradition, whose sources in Islamic civilization were largely written in Arabic and Persian, did not receive much attention.

In the Ottoman translation tradition, the source languages were largely Arabic and Persian. Within this tradition, Arabic is by far the leading source for non-literary translation activities, whereas Persian texts are the source for literary translation activities. While these two languages served as direct sources for translation activities, they were also indirectly involved as intermediary languages in the translation of some Indian and Greek texts into Turkish. Assertions such as "With the Ottomans, there was no translation from the West until the $17^{\text {th }}$ century" (Aksoy 2005: 952), which have been quoted in some sources that provide information about translation activities during the Ottoman period, need to be corrected. Until the end of the eighteenth century, languages such as Greek, Latin, French and German were the source languages of those numerically limited Western translations; in the nineteenth century, however, other Western languages such as English, Italian, Russian, Bulgarian and Croatian were added over time (Yazar 2011: 1195).

The very first evaluations of translation activities in the Ottoman period were based on the work of Hilmi Ziya Ülken, Uyanış Devirlerinde Tercümenin Rolü, published in 1935. Reading Ülken's assessments of translation activity in the Ottoman period reveals that he developed a very negative view that made the translations produced in the Ottoman period appear completely insignificant. He regarded them as simple, rendered them worthless in their effect and sharpened them in a narrow range. This negative view can have various causes; however, we believe that one of the reasons that played an important role in the formation of this view is that the author did not have solid bibliographical information about the translation activities mentioned, and the other reason is the Western-oriented "evaluation" that had gradually ceased to be effective since the early Tanzimat.

Long after Ülken's research, especially since the late 1990s and early 2000s, further studies have been published that provide information on the translation activities on the Ottoman period. These studies generally seem to be carried out by researchers from the university departments of Turkish language and literature and Eastern languages and literatures and relatively new disciplines such as the history of science, and translation and interpreting studies.

Nevertheless, there are not many scholarly publications on the history of Ottoman translation in the field of Translation Studies in Turkey. This may be because the researchers have not been trained adequately to deal with these translated texts, in particular, in that they lack knowledge of Ottoman Turkish. 
The Department of Translation Studies at Boğaziçi University has a unique status in the field of translation studies in the Ottoman period. In particular, under the direction of Saliha Paker, it can be noted that some studies based on primary sources, which benefit from the accumulation of Classical Turkish Literature research, have been and are being conducted on an ongoing basis in collaboration with the Department of Turkish Language and Literature at the same university.

Most of the studies carried out by researchers in the field of Turkology (especially those in the field of Classical Turkish Literature) on translation activities in the Ottoman period are bibliographical. The number of studies that problematize translation, approach translation texts through the lens of translation studies and analyze these translations in comparison with the source texts is very small and insufficient in comparison with the existing larger translation literature.

However, in the field of Ottoman translation history, there are many avenues and terrains to investigate. Therefore, making an inventory of the translation activities developed during this period, preparing their critical editions, making them available for study in various disciplines, comparing these translations with the source texts using translation-critical theories and some other ways of making the Translation Studies, are primarily topics that await researchers. Also, the Ottoman translation tradition offers original fields of research in Translation Studies in such areas as the translation of poems, retranslation, plagiarism through retranslation, patronage in translation, culture-specific translation concepts, translation theory and theories. Researchers who will be working in this field are expected to have at least a minimum level of competence, such as knowledge of the languages of the translations produced during the period in question and of the source languages from which the texts originate; reading, understanding and internalizing the theories developed for translation criticism; and for literary translations, a minimum knowledge of the literary traditions of the languages in which both the source and target texts are produced. 


\section{GÍRİŞ}

Batı'da XX. yüzyılın başından itibaren çeviri olgusu ve etkinliklerine dair araştırmalarda tedricî olarak bir artış yaşanmış, bu yüzyılın ikinci yarısıyla birlikte çeviriye duyulan ihtiyaç ve artan ilgi, çeviribilim disiplininin doğmasını hazırlamıştır. Çeviribilim disiplini altında daha yoğun ve sistemli bir görünüm kazanmaya başlayan çeviriye yönelik araştırmalarda, güncel çeviri etkinliklerine yönelik araştırmalar yapıldığı gibi çeviri tarihine yönelik de birçok araştırma ve inceleme yapılmıştır. Woodsworth'un da ifade ettiği üzere, son yıllarda çeviri tarihine yönelik ilginin arttığını gösteren birçok bilimsel faaliyet görülmektedir: Pek çok bilimsel etkinlik düzenlenmiş, kitap ve makaleler yazılmış ve bazı büyük projeler başlatılmıştır. Tüm bunlara rağmen tercüme tarihine dair araştırmalar yapan bilim insanları, tekrar tekrar yeni çalışmaların yapılması gerektiğini vurgulamaktadırlar. (Woodsworth, 2005: 100)

Çeviri uygulamalarının tarihi genellikle, "Ne, kim tarafindan ve hangi şartlar altında ve hangi sosyal veya politik bağlamda tercüme edildi?" gibi sorularla ilgilenir. Çeviri teorisinin tarihiyle ilgilenen çalışmalar ise; "Mütercimler, kendi sanat-zanaat-bilimleriyle ilgi ne düşünüyorlardı?”, "Tercümeler farklı dönemlerde nasıl değerlendirildi?", "Mütercimler ne tür tavsiyelerde bulundular?” gibi sorulara cevap bulmaya çalışır.

Edmond Cary, Theodore Savory, George Steiner, Louis Kelly ve Susan Bassnett gibi araştırmacıların; geçmişteki mütercim ve tercümeler, genel tercüme tarihi ve Batı'daki tercüme teorileri ve uygulamaları üzerindeki öncü çalışmalarından sonra, her biri farklı yollarla tercüme tarihinin sınırlarını çizen ve geçmişe farklı merceklerle bakan makale, monografi ve ortak çalışma projelerinde artış olmuştur. Ülke, bölge, dilbilimsel veya kültürel ortaklığın dikkate alındığı çeviri tarihi araştırmalarının, Antik Çağlar, Orta Çağlar ve Rönesans gibi kültürel tarih dönemlendirmeleri ile tezahür ettiği görülebilmektedir. Benzeri şekilde Bağdat ve Toledo Okulları gibi büyük tercüme dönemleri de bu dönemlendirmelerde ölçüt olabilmektedir. Çeviri tarihine yönelik araştırmaların bir kısmını da edebî tercümelere dair çalışmalar oluşturmaktadır. Orta Çağlar'daki kutsal metinler, Quebec'teki tiyatro tercümeleri gibi çalışmalar bu türdendir. Edebiyat çevirisi tarihine bir diğer yönelim biçimi de başarılı tercümeler, Homeros veya Shakespeare gibi büyük yazarlardan yapılan tercümeler ya da Arap Geceleri gibi metinlerin tercümeleri üzerine çalışmaktır. İncil ve diğer kutsal kitapların tercümeleri de yine başka bir çeviri tarihi araştırmaları biçimidir. Dinî, bilimsel, teknik tercümeler de az da olsa bu sahada yapılan araştırmalara konu olabilmektedir. (Woodsworth, 2005: 100-101)

Batı'daki çeviribilim araştırmalarına göre biraz daha geç başlamış olan Türkiye'de de çeviri araştırmaları farklı disiplinlerin cılız katkılarıyla başlamış, 2000'li yıllardan itibaren ise çeviribilim ve Türkoloji sahasındaki araştırmacıların daha görünür olmaya başlayan çalışmalarıyla artarak devam etmiş/etmektedir; ancak bunların büyük bir bölümü Cumhuriyet dönemi, az bir kısmı da Tanzimat sonrası Batı kaynaklı çevirilere odaklanmakta olup XIII. yüzyıldan başlayarak Cumhuriyet dönemine kadar süren uzun dönemde Batı Türkçesiyle yapılan tercümeler, özellikle de müşterek İslam medeniyeti kaynaklı tercüme faaliyetleri 
yeteri kadar ilgiyi çekmemiştir. Oysa XIII. yüzyıldan başlayarak yaklaşık altı yüz yıllık uzun bir süreçte, Batı Anadolu'da Germiyanoğulları ve Aydınoğulları, kuzeyde Candaroğulları ve Kırım Hanlığı, doğuda Akkoyunlular, güneyde de Memlükler gibi beylik ve devletler, ancak daha ziyade Osmanlılar döneminde geniş bir zaman ve sahada Batı Türkçesi ile oluşturulan köklü ve geniş bir tercüme geleneğinin bulunduğunu, ve bu geleneğin halihazırda farklı araştırma ve incelemelere konu olabilecek bakir bir alan olarak araştırmacıları beklediğini ifade etmek gerekir.

Arapça ve Farsça bu tercüme geleneğine kaynaklık eden temel iki dildi. Kaynak dilleri bağlamında genel bir değerlendirmeye tabi tutulacak olursa, Osmanlı döneminde üretilmiş edebiyat dışı tercüme faaliyetlerine kahir ekseriyetle Arapçanın kaynaklık ettiği; ancak edebî tercüme etkinliklerinde ise daha çok Farsça metinlerin kaynak alındığı görülmektedir. Öte taraftan esmâü'l-hüsnâ, hilye, hadis (kırk ve yüz hadis gelenekleri), peygamber kıssaları, Hz. Ali’nin özlü sözleri gibi dinî edebiyat kapsamına dahil edilebilecek tercümeler ve belagat konusundaki tercümelerde Arapçanın kaynaklığı barizdir. Arapça ve Farsça, Osmanlı dönemi çeviri etkinliklerine dolaysız bir şekilde kaynaklık ettikleri gibi, Yunan ve Hint kaynaklı kimi metinlerin Türkçeye tercüme edilmesinde vasıta/aracı dil olarak da kullanılmıştır. Osmanlı döneminde Arapça ve Farsça dışında Kürtçeden de tercüme yapılmışsa da bu Mem ü Zîn ve birkaç eserin tercümesiyle sınırlı kalmıştır. Osmanlı dönemindeki tercüme faaliyetleri ile ilgili kimi kaynaklarda öne sürülen "Osmanlılarda XVII. yüzyıla kadar Batı'dan hiçbir tercüme yapılmamıştı.” (Aksoy, 2005: 952) şeklindeki yargı ise tashihe muhtaçtır. Zira yapılan araştırmalar göstermektedir ki Osmanlı dönemi tercüme geleneğinde, sözlü çeviri etkinliklerini gerçekleştiren tercümanlar/dilmaçlar bu dönemden önce de bazı Batı kaynaklı eserleri Türkçeye tercüme etmişlerdir. Bu daha sınırlı sayıda gerçekleştirilen Batı kaynaklı çevirilerde XVIII. yüzyılın sonlarına kadar, Rumca (Yunanca), Latince, Fransızca ve Almanca gibi diller kaynak olurken XIX. yüzyıldan itibaren bunlara İngilizce, İtalyanca, Rusça, Bulgarca, Hırvatça gibi diğer Batı dilleri de eklenmiştir. (Yazar, 2011: 1195)

Aynı zamanda Osmanlı çeviri tarihine yönelik araştırmalara bir davet olması beklenen bu makale, temelde Tanzimat öncesi Osmanlı tercüme geleneğine yönelik araştırmalarda ne aşamada olduğumuzu tespit edip bu sahadaki boşluk ve zorluklara işaret etmeyi amaçlamaktadır. $\mathrm{Bu}$ doğrultuda; makalenin birinci kısmında daha ziyade Türkiye' de Osmanlı tercüme tarihine yönelik şu ana kadar yapılan araştırmalar, bu araştırmaları yapan araştırmacıların mensup oldukları bilimsel disiplinlere göre sınıflandırılıp bazı temsilci çalışmalar zikredilerek betimlenmeye çalışılacaktır. Bu bölümü müteakiben gelecek “Bundan Sonra Neler Yapılabilir” başlığını taşıyan kısımda ise bazı araştırma sorularıyla desteklenerek Osmanlı tercüme geleneğinin araştırma ve incelemeye açık alanlarına işaret edilecektir. Böylece çeviribilimin alanını genişletip çeşitlendirecek, Türkoloji sahasında ise bu türden tercüme metinlerine yönelik daha nitelikli araştırma ve incelemelerin ortaya çıkmasına katkı sağlayacak şekilde Osmanlı tercüme geleneğinin bakir bir alan olarak araştırmacıları beklediği vurgulanmaya çalışılacaktır. Makalenin sonuç kısmında ise; bir kısmı Türkiye’ye özgü şartlardan ötürü Osmanlı tercüme tarihini çalışmanın, araştırmacıları çok yönlü bir donanıma sahip olup disiplinlerarası çalışmaya 
zorladığı üzerinde durulduktan sonra bu türden araştırmalar yapmak için asgari düzeyde aranabilecek yeterliklere dair bir değerlendirme yer alacaktır.

\section{Bir Muhasebe: Şu Ana Kadar Ne Yapıldı?}

Osmanlı dönemindeki tercüme faaliyetleri hakkında ilk derli toplu bilgi ve değerlendirmeler, uzun bir dönem Hilmi Ziya Ülken' in ilk baskısı 1935 'te yapılan Uyanıs Devirlerinde Tercümenin Rolü isimli çalışmasına dayanmaktaydı. Neşredildiği tarihten itibaren onlarca yıl kaynak eser olarak kullanılan ve günümüzde bile özellikle tercüme ile ilgili araştırmalarda sıklıkla başvurulan bu eserde; muhtelif başlıklar altında tercüme faaliyetlerinin, milletlerin kültürel ve medeni uyanışlarında oynadığı rol üzerinde durulmaya çalışılmıştır. Bahsi geçen çalışmasında “Osmanlılar Devrinde Tercüme” başlıklı bir bölüm açan Ülken, bu bölümün ilk paragrafında Osmanlı devri tercüme faaliyetleri ile ilgili genel bir değerlendirme yaptıktan sonra, Beylikler döneminden başlayarak Tanzimat döneminin sonuna kadar yüzyılları esas alarak seçtiği bazı tercümelere yer verir. Ülken'in Osmanlı dönemi tercüme faaliyetleri hakkındaki değerlendirmeleri okunduğunda; onun Osmanlı döneminde yapılan tercümeleri; bütünüyle önemsizleştiren, basit gören, etkisi bakımından değersiz kılan, dar bir alana sıkıştıran çok olumsuz bir bakış açısı geliştirdiği görülmektedir. Bu olumsuz bakış açısının farklı sebepleri olabilir; ancak yazarın bahsi geçen bu tercüme faaliyetleri hakkında sağlam bir bibliyografik kaynağa sahip olmaması ve Tanzimat'tan beri tedrici olarak etkisini arttıran Batı merkezli “değer”lendirmenin çok önemli bir rol oynadığını düşünüyoruz. ${ }^{1}$ Nitekim bugün artık Batılılaşmadaki etkisi tartışılmaz olan XIX. yüzyıldaki (Tanzimat Dönemi) Batı kaynaklı tercümeler de onun bu olumsuz bakış açısından nasibini almıştır.

Ülken'in bu çalışmasından uzun bir süre sonra, özellikle de 90'lı yılların sonları ile 2000'li yılların başından itibaren Osmanlı dönemi tercüme faaliyetleri hakkında bilgi veren başka çalışmalar da neşredilmiştir. Bu çalışmaların genel olarak üniversitelerin Türk dili ve edebiyatı, Doğu dilleri ve edebiyatları ile bilim-felsefe tarihi ve çeviribilim (mütercim-tercümanlık) gibi görece yeni disiplinlere mensup araştırmacılar tarafından yapıldığı anlaşılmaktadır.

Çeviribilim (mütercim-tercümanlık) bölümlerine bakıldığında, gerek uygulama gerekse kuramsal alanla ilgili olarak Osmanlı dönemi çeviri tarihine dair çok fazla bilimsel araştırma ve inceleme ile karşılaşılmadığı gibi, bu bölümlerin gerek lisans gerekse lisansüstü programlarının ders müfredatları incelendiğinde, birkaçı hariç Osmanlı dönemi tercüme tarihine yönelik bir ders bulunamamıştır. Şüphesiz bu durum için farklı sebepler zikredilebilir; ancak bu bölümlerden mezun olan araştırmacı ve öğretim üyelerinin, başta Osmanlı Türkçesi bilgisi olmak üzere, bu tercüme metinleriyle muhatap olabilmeyi mümkün kılan bir formasyondan geçemediklerinden bu dönemde oluşturulmuş metinleri inceleyememeleri öncelikli olarak akla gelebilecek bir sebeptir. Bunun yanında; özellikle çeviribilimin bir muhitinde egemen olan, daha ziyade

1 Hilmi Ziya Ülken ve onun bahsi geçen eserini kaynak alan bazı araştırmacıların Osmanlı dönemi tercüme geleneğine yönelik değerlendirmelerinin yakın zamanda neşretmeyi düşündüğümüz bir makalede ele alınması düşünüldüğünden burada ayrıntılı bir değerlendirmeden kaçınılmıştır. 
Batı kaynaklı tercümeleri önemli gören, İslamî kaynaklı tercümeleri ise öteleyen bir bakış açısının da bunda payı olsa gerektir. Bununla birlikte, büyük oranda Hilmi Ziya Ülken'in bahsi geçen çalışması gibi ikinci elden kaynaklardan hareketle yapılan bazı araştırmalar da yok değildir; Sakine Eruz, İlyas Öztürk ve Mine Yazıcı'nın kitaplarında; Alparslan Yasa'nın (Yasa, 2003) Fransızca makalesinde ve Berrin Aksoy’un bütünüyle ikinci elden kaynaklar üzerinden hazırlanan "Translation Activities in the Ottoman Empire" başlıklı makalesinde, Osmanlı tercüme tarihine dair bilgiler bulunabilir. Ancak bu çalışmalarda, büyük oranda $\mathrm{H}$. Ziya Ülken'in çalışması kaynak alınmış olup birinci elden kaynaklar bir tarafa, uzmanlık sahası bizzat bu metinlerden oluşan klasik Türk edebiyatı sahasındaki araştırmalar ya da çalışmamızın ilerleyen kısımlarında üzerinde durulacak Boğaziçi Üniversitesi Çeviribilim Bölümünün çalışmalarından çok az istifade edilmiştir. Hal böyle olunca, Osmanlı dönemindeki tercüme faaliyetlerini önemsizleştiren ve değersizleştiren, bu tercüme geleneğini kendi iç dinamiklerine göre değerlendirmekten uzak bakış açısı, olduğu gibi bu çalışmalara da yansımış olup yapılan tercümelere Batı kaynaklı olup olmamasına göre değer atfedilmiştir. Bundan dolayıdır ki, Çeviribilim sahasında yapılan araştırmalarda Osmanlı dönemindeki sözlü tercüme (dilmaçlık) faaliyetleri ile XIX. yüzyılda konu yelpazesi genişleyerek yoğunlaşan Batı kaynaklı tercümeler üzerinde daha fazla durulmuştur.

Berrin Aksoy'un makalesi (Aksoy, 2005) bu durumu net olarak ortaya koyan iyi bir örnek olabilir. "Translation" ve "Ottoman" kelimeleri ile yapılacak en basit bir arama/taramada bile karşımıza ilk çıkacak veri olacak kadar erişimi kolay olan bu çalışma, bizzat yazarının da ifade ettiği üzere ikinci elden kaynaklardan hareketle hazırlanmasına karşın, daha özet bölümündeki ilk cümle "Osmanlılarda on sekizinci yüzyıla kadar tercüme faaliyetlerine fazla ehemmiyet verilmemiştir”’2 mealinde olup Ülken'den ödünç alınan olumsuz bakış açısı bu makaleyle daha geniş bir kitleye yayılmıştır.

Çeviribilim bölümleri arasında, Boğaziçi Üniversitesi Çeviribilim Bölümünü, Osmanlı dönemi tercüme tarihine dair yapılan araştırmalar ve incelemeler noktasında farklı bir yerde konumlandırmak mümkündür. Hassaten Saliha Paker'in önderliğinde bu bölümde, bahsi geçen üniversitedeki Türk Dili ve Edebiyatı bölümüyle de işbirliği yapılarak tercüme tarihi konusunda, birinci elden kaynaklara dayanan ve klasik Türk edebiyatı araştırmalarının birikiminden de istifade edilen bazı bilimsel araştırmaların yapılmaya başlandığ 1 ve zamanla bunların artarak devam ettirildiği görülmektedir. Her şeyden evvel söz konusu bölümün doktora programında, diğer birçok çeviribilim bölümlerinin ders müfredatında bulunmayan "History of Translation in Ottoman Turkish” gibi konuyla doğrudan alakalı birkaç ders verilmektedir. ${ }^{3}$ Aynı şekilde, son zamanlarda Tanzimat dönemindeki çeviri etkinliklerinin de bu bölümdeki yüksek lisans veya doktora tezlerine konu edildiği gözlemlenmektedir. ${ }^{4} \mathrm{Bu}$ tür çalışmaların oluşmasında Saliha Paker'in Hilmi Ziya Ülken ve Köprülüzâde Mehmed Fuad gibi bazı edebiyat tarihçilerinin

\footnotetext{
"In the Ottomans, translation activities took place without much significance until the 18th century" Bk. https://transint.boun.edu.tr/phd-curriculum

Çeviribilim sahasında, Tanzimat sonrası Batı kaynaklı tercümelere yönelik yapılan araştırmaların önemli bir kısmı Cemal Demircioğlu tarafından kısa bir değerlendirmeye tabi tutulmuştur. Bkz. (Demircioğlu, 2016)
} 
Osmanlı tercüme geleneğine yönelik paradigmalarını aşarak etrafında topladığı araştırmacıları birincil kaynaklar üzerinden Osmanlı çeviri tarihine yönlendirmesi çok önemli rol oynamıştır. Çeviribilim çıkışlı araştırmacıların sahip olduğu formasyon ve sınırlı imkanlar ile Osmanlı Türkçesi ile yazılan metinleri okuyup anlamada yetersiz olduklarının farkında olan Paker, başta Zehra Toska olmak üzere Boğaziçi Üniversitesinin Eski Türk Edebiyatı kürsüsündeki araştırmacılar ile disiplinlerarası çalışmalar yürütmüştür. "Osmanlı Edebiyat Modellerinin Oluşumunda Beylikler Döneminde Yapılan Tercümelerin İşlevleri.”, "Eski Türk Edebiyatının Kültür Oluşumunda Çevirilerin Rolü.” başlıklı projeler kapsamında beraber çalışma firsatı bulan bu araştırmacılar, bu çalışmalarının sonuçlarını birkaç makale ile ilim âlemiyle paylaşmışlardır. Demircioğlu tarafından ayrıntılı olarak özetlenip değerlendirilen bu sonuçlarda genellikle şu görüşlerin öne çıktığı söylenebilir.

1. Osmanlı çeviri tarihine yönelik Batı merkezli bakış açısı ve değerlendirmenin terk edilip Tanzimat öncesinde de on üçüncü yüzyıldan başlayarak gelişmeye başlayan ve izleri en azından Cumhuriyet dönemine kadar kesintisiz olarak takip edilen bir tercüme geleneğinin varlığı unutulmamalı ve bu tercüme geleneği ötelenmemelidir. (Toska ve Paker, 1997; Toska, 2000, 2002)

2. Özellikle Paker'in vurgusuyla, Osmanlı çeviri tarihini çalışırken kültüre ve zamana özgülüğü gözden kaçırmamak, bu anlamda Osmanlı döneminde çeviri olgusunun modern görünümlerdeki gibi net/açık ve tek yönlü olmadığını; nazire, şerh, telhîs, muhtasar gibi farklı kavramlar ile muhtelif tür ve şekillerde görünüm kazandığını, çeviri-telif arası sınırların daha bulanık, daha karmaşık olduğunu unutmamak gerekir. Bu anlamda Paker, "terceme” kavramının günümüzde "tam çeviri”ye karşılık gelemeyeceğini ileri sürer. (Paker, 2002, 2007, 2009)

3. Mehmed Fuad Köprülü’nün araştırmaları başta olmak üzere, Cumhuriyet döneminde kaleme alınan edebiyat tarihleri gibi bazı ikincil kaynaklar, Osmanlı dönemi tercüme etkinliklerini daha ziyade ulus-devlet bakış açısıyla “değer”lendirmektedir. Bu ise açık ya da örtük bir biçimde Osmanlı dönemi tercüme faaliyetlerini ötelediği, bu tercüme geleneğini kendi gelişimi çizgisinde ve kendi değer ölçütleri ile değerlendirmeyi engellediği için bu türden ikincil kaynakların eleştirel okumalara tabi tutulması gerekir. (Paker, 2004, 2014)

Saliha Paker, özellikle çeviribilim sahasında Osmanlı çeviri tarihine bakışı köklü bir şekilde değiştiren ve yönlendiren neşirleri yanında, editörlüğünü yaptığı Translations: (Re)shaping of Literature and Culture başlıklı Tanzimat sonrası Batı kaynaklı çeviriler ve klasik Osmanlı dönemi tercüme faaliyetlerine dair birkaç araştırmayı ihtiva eden kitabıyla da bu katkılarını çeşitlendirmiştir. ${ }^{5}$

Paker'in Osmanlı tercüme tarihine dair önemli bir diğer katkısı da Türk dili ve edebiyatı bölümünden mezun olan Cemal Demircioğlu'nu bu sahaya yönlendirmiş olmasıdır. “From

52018 y1lında Saliha Paker'e armağan olarak neşredilen Journal of Turkish Studies (Türklük Bilgisi Araştırmalarl) dergisinin 49. sayısı da benzer şekilde Osmanlı çeviri tarihine yönelik makalelerden oluşmaktadır. 
Discourse to Practice: Rethinking "Translation" (Terceme) and Related Practices of Text Production in the Late Ottoman Literary Tradition" (Demircioğlu, 2005) adıyla, Tanzimat sonrası Osmanlı edebiyatındaki "terceme" kavramını ele alan doktora çalışmasıyla bu alandaki önemli bir boşluğu dolduran Demircioğlu, son on yıl içerisinde bir kısmı Tanzimat öncesi Osmanlı çeviri geleneğine de uzanan birkaç makale neşretmiştir. (Demircioğlu, 2006; 2009; 2018) Erken dönem makalelerinde daha ziyade XIX. yüzyıl ve klasik Osmanlı dönemi öncesi çeviri kavramları üzerinde durup Saliha Paker'in geliştirdiği “kültüre ve döneme özgü’lüğün izlerini kavramlar bağlamında takip eden Demircioğlu'nun; son birkaç çalışmasında ise Osmanlı çeviri tarihini çalışmanın sorunlarını dile getirerek (Demircioğlu, 2008) ve Osmanlı çeviri kuramının izlerini sürerek (Demircioğlu, 2013) araştırmalarını çeşitlendirmeye çalıştığı görülmektedir. Demircioğlu son olarak Çeviribilimde Tarih ve Tarihyazımı (Demircioğlu, 2016) başılıkı bir kitap neşretmiştir. Bu kitabının önemli bir kısmını Osmanlı tercüme geleneğine ayıran araştırmacı, öncelikle daha çok çeviribilim sahasında Osmanlı çeviri tarihine yönelik yapılan çalışmaları değerlendirmiş, ardından Osmanlı tercüme etkinliklerini incelemeye yönelik -örnek uygulamalar eşliğinde- tekliflerde bulunmuştur. Boğaziçi Üniversitesi Çeviribilim Bölümü muhitindeki bu önemli çalışmaların dışında, Türkiye'de az sayıdaki diğer çeviribilim bölümlerinde Tanzimat öncesi Arapça ve Farsça kaynaklı tercüme geleneğine yönelik ilginin çok sınırlı olduğu, yeni yeni oluşmaya başlayan ilginin ise çalışmamızın ilerleyen bölümlerinde değinilecek şartlardan dolayı semeresiz kaldığı görülmektedir.

Daha ziyade Abbasi dönemi tercüme etkinlikleri üzerinde duran Doğu dilleri ve edebiyatları bölümleri ile ilahiyat fakültelerinin ilgili bölümlerinde de Osmanlı dönemindeki Kur'ân tercümelerine yönelik birkaç araştırmanın yapıldığı görülmektedir. Ancak bu alanda yapılan araştırmaların Osmanlı tercüme geleneğiyle ilişkilendirilmesi, Osmanlı dönemindeki dinî kaynaklı tercümelerin izlerini sürme ya da Arapça ve Farsça kaynaklı bir tercümeyi kaynak metni ile karşılaştırma şeklindeki araştırma ve incelemelerle pek karşılaşılmamaktadır.

Bu bölümlerin yanında; bilim-felsefe tarihi ve diğer ilim sahalarında çalışan birkaç bilim insanı da Osmanlı dönemindeki tercüme faaliyetlerini konu alan araştırmalar yapmıştır. $\mathrm{Bu}$ bağlamda; Ramazan Şeşen'in, Osmanlı sahasındaki tercümeler konusunda yazdığı "Onbeşinci Yüzyılda Türkçeye Tercümeler” (Şeşen, 1991) ve Lale devrindeki yoğun tercüme dönemiyle ilgili yazdığı "Lale Döneminde Yenileşme Hareketleri ve Tercüme Edilen Eserler" (Şeşen, 2004) başlıklı makaleleri bahsi geçen dönemlerdeki tercüme envanterini çıkarmaya yönelik öncü çalışmalar arasında yer alır. Feza Günergun ve Ceyda Özmen de Osmanlı'da Batı kaynaklı bilim çevirisine dair birer makale kaleme almışlardır. Günergun "Osmanlı'nın Avrupa Bilimi ile Münasebetleri 16-17. yy.'da Türkçe Çeviriler" (Günergun, 2012) başlıklı makalesinde Batı biliminin Osmanlı'ya girişini tercümeler üzerinden okumaya çalışıken Özmen de "Osmanlı İmparatorluğu'nda Bilimi Çevirmek: Osmanlı Bilim Repertuarlarında 'Değişim Özneleri' Olarak Mütercim-Hocalar (1789-1839)" (Özmen, 2016) başlıklı çalışmasında aynı konuyu mütercim-hocalar üzerinden değerlendirmeye çalışmıştır. İhsan Fazlığlu'nun tercüme tarihinin kuramsal yönüyle alakalı olarak, Osmanlı dönemindeki tercümelerin diline dair yazdığı 'Osmanlı Döneminde 'Bilim' Alanındaki Türkçe Telif ve Tercüme Eserlerin Türkçe 
Oluş Nedenleri ve Bu Eserlerin Dil Bilincinin Oluşmasındaki Yeri ve Önemi” (Fazlığlu, 2003) başlıklı makalesi, muhatap okuyucu kitlesi üzerinden erken dönem Osmanlı Türkçe telif ve tercüme metinlerinin değerlendirildiği bir diğer çalışmadır. Yine felsefe sahasındaki çalışmalarıyla tanınan Bekir Karlığa’nın da Boğaziçi Üniversitesi Çeviribilim Bölümünün bir etkinliği olarak sunduğu “Osmanlı Bilim ve Düşüncesinin Kuruluş Döneminde Tercümenin Rolü” başlıklı semineri bu tercüme etkinliklerine yönelik bilimsel araştırmalar arasında yer almaktadır. Taceddin Kayaoğlu'nun Türkiye'de Tercüme Müesseseleri başlıklı kitabında (Kayaoğlu, 1998) XVIII. yüzyıldan itibaren görünür hale gelen tercüme kurumları hakkında bilgi vermiştir. Sezai Balcı'nın “'Osmanlı Devleti'nde Tercümanlık ve Bab-1 Ali Tercüme Odası” başlıklı doktora çalışması da Osmanlı'daki sözlü tercüme geleneğine yönelik arşiv belgelerine dayalı bir çalışma olup konuyla ilgili (sözlü çeviri) birincil kaynaklara dayalı en kapsamlı çalışma olarak değerlendirilebilir. (Balcı, 2006) ${ }^{6}$

Uzmanlık sahası gereği bizzat bu tercüme metinleriyle özellikle de edebî metinlerin tercümeleriyle iştigali gerektiren Türk dili ve edebiyatı bölümlerinde ise Osmanlı dönemi tercüme faaliyetleri hakkında nispeten daha fazla araştırmanın yapıldığı gözlemlenmektedir. Yapılan bu araştırmaların bu bölümlerdeki anabilim dallarının uzmanlık sahasına göre farklı dönemlere yönelik olarak gerçekleştiği söylenebilir. Yeni ya da eski Türk dili anabilim dallarındaki araştırmacıların İslamiyet öncesi dönemlerde ya da Beylikler dönemiyle erken Osmanlı devrelerinde üretilmiş tercüme faaliyetlerine odaklandıkları müşahede edilmektedir. Eski Türk edebiyatı anabilim dalındaki öğretim üyeleri, daha ziyade Osmanlı dönemi edebî metinlerin tercümelerini çalışmalarına bahis mevzusu yaparken, yeni Türk edebiyatı anabilim dalındaki araştırmacıların, genellikle Tanzimat sonrası yapılan Batı kaynaklı edebî tercümeler üzerinde yoğunlaştıkları görülmektedir.

Bu bölümlerde, tercüme tarihine yönelik yapılan araştırmaların bir kısmı tercüme faaliyetlerinin dökümünü çıkarmayı hedefleyen çalışmalardır. Nurgül Sucu'nun "Eski Türk Edebiyatı'nda Tercüme Geleneği”" (Sucu, 2006) başlıklı makalesi bu türden bir amaç gütse de makale sınırlı bir envanter sunmaktadır. Sadık Yazar'ın 2011 yılında tamamlanmış “Anadolu Sahası Klasik Türk Edebiyatında Tercüme ve Şerh Geleneği” başlıklı basılmamış doktora çalışmasında (Yazar, 2011), yazma eser kütüphaneleri başta olmak üzere kataloglar, klasik biyografik ve bibliyografik kaynaklar ile konuyla doğrudan ya da dolaylı olarak ilgili çalışmalar taranarak XIII. yüzyıldan XIX. yüzyılın başına kadar, Osmanlı dönemi tercüme faaliyetlerinin mevcut en kapsamlı dökümü ortaya konmuştur. Yazar, bu döküm üzerinden Osmanlı tercüme ve şerh geleneğine dair genel bir değerlendirme de yapmaya çalışmıştır.

Bu türden döküm çıkarma çalışmalarının bir kısmı da Kasîde-i Bürde, Mesnevî-i Ma'nevî, Gülistân, Leylâ ve Mecnûn ve Tezkiretü'l-Evliyâ gibi müşterek İslamî edebiyatların çokça okunan metinleri arasında yer alan eserlerin Osmanlı dönemi Türk edebiyatındaki farklı

6 Balcı'nın bu çalışması neşredilmiştir. (Balcı, 2013) Arzu Meral'in “A Survey of Translation Activity in the Ottoman Empire" başlıklı Batı kaynaklı tercüme faaliyetlerinin seyrini verme gayesi taşıyan makalesinin ilk bölümü de Osmanlı dönemi sözlü çeviri üzerinde duran bir çalışmadır. (Meral, 2013) 
tercümelerinin (kimi çalışmalarda şerhlerin de dahil edilmesiyle) konu edildiği çalışmalardır. Abdülkadir Karahan'ın İslam Türk Edebiyatında Kırk Hadis: Toplama, Tercüme ve Şerhleri başlıklı kitabı (Karahan, 1991), Nihat Öztoprak'ın 'Klasik Türk Edebiyatında Manzum Yüz Hadisler" (Öztoprak, 1993), Belal Saber Mohamed Abd el-Maksoud'un "Leylâ ile Mecnûn Mesnevisinin Arap, Fars ve Türk Edebiyatı'nda Ele Alınış Biçimi ve Larendeli Hamdî’nin Eseri” (Abd el-Maksoud, 2004), Ahmet Kartal'ın “Sa'dî-i Şîrâzî’nin Gülistân İsimli Eserinin Türkçe Tercümeleri” (Kartal, 2001) Ebubekir Sıddık Şahin'in “Kasîde-i Bürde’nin Türkçe Şerh ve Tercümeleri” başlıklı tezi (Şahin, 1997), İsmail Güleç'in Türk Edebiyatında Mesnevî Tercüme ve Şerhleri (Güleç, 2008) adlı kitabı bu nevi araştırma ve incelemeler bağlamında hatırlanabilir. Benzer bir çalışma şekli de meşhur şair veya müelliflerden yapılan çevirilerin değerlendirildiği çalışmalardır. Haşim Koç’un “Cultural Repertoire as a Network of Translated Texts: the New Literature After the Tanzimat Period (1830-1870)" başliklı tezi (Koç, 2004), Zeynep Kerman'ın 1862-1910 Yılları Arasında Victor Hugo'dan Türkçeye Yapılan Tercümeler Üzerinde Bir Araştırma başlıklı kitabı (Kerman, 1978) bu türden araştırmalara örnek verilebilir. Bir tercüme metninin neşrini gaye edinen çalışmaların girişlerinde de varsa aynı eserin diğer tercümeleri tanıtılarak da benzer şekilde envanter çıkarma çalışması yapılabilmektedir.

Klasik Türk edebiyatı araştırmacılarının tercüme ve tercüme etkinlikleri ile ilgili olarak yaptıkları bu araştırmaların büyük bir bölümü bibliyografik bir mahiyette olup, tercümeyi sorunsallaştıran, eldeki tercüme metinlerini tercüme nokta-i nazarından ele alan, bu tercümeleri kaynak metinleriyle karşılaştırmalı olarak inceleyen çalışmaların sayısı eldeki tercüme külliyatına oranla oldukça az ve yetersizdir. Nitekim Zehra Toska da klasik Türk edebiyatı sahasında yapılan araştırmalarda, çalışma konusu yapılan eserin telif mi tercüme mi olduğuna dikkat edilmeden, kaynak metinle tercüme arasında ilişki kurulmadan bu eserin edebi değerinden söz etmenin çok da isabetli olmayacağını zımnen ifade ederken tercüme metinler söz konusu olduğunda yapılması öncelikli olarak gerekli olduğu halde yapılamayan/sorunsallaştırılmayan konulara şu şekilde değinir:

Tercüme metinler üzerine konuşurken bu metnin tercüme ölçütlerinin ne olduğu, mütercimin tercümede izlediği strateji, kaynak metnin kavram ve terimlerine hangi karşılıkları bulduğu, kısaca kaynak metinle kendi metni arasında kurduğu ilişkiler sorgulanmıyor. Bu tür değerlendirmeler ne kadar sağlıklı olabilir? Ayrıca mütercim/ şair/yazarın tercüme ettiği eserlerle varsa telif eserlerini dil ve üslup açısından karşılaştırmak gerekmez mi? Bu ön çalışmalar yapılmadan, sadece tercüme eser üzerinden onların edebi şahsiyetleri hakkında görüş bildirmek yanıltıcı olmaz mı? (Toska, 2000, s. 293)

Sadece klasik Türk edebiyatı sahasında değil dil alanında yapılan çalışmalarda da benzer şekilde neşri yapılan tercüme metinlerin tercüme bağlamında pek incelenmediği görülmektedir. Bununla birlikte bu türden incelemeler bütünüyle yok değildir; Cem Dilçin, Mantıku 't-Tayr'ın Osmanlı döneminde yapılan manzum tercümelerini birbiriyle karşılaştırdığı makalesiyle bu sahada öncü bir çalışma gerçekleştirmiştir. (Dilçin, 1993) Zehra Toska'nın Nedret Kuran Burçoğlu 
ile birlikte 1997 yılında İngilizce, 2010 yılında da Türkçe olarak neşredilen "Ferideddin-i Attar'ın Mantıku't Tayr adlı Yapıtı'nın 14, 16, 17 ve 20. Yüzyıllarda Yapılmış Türkçe Yeniden Yazımları" başlıklı çalışması da bu türden tercümeler arası karşılaştırmalı bir çalışmadır. (Toska ve Kuran Burçaoğlu, 2010) Uygulama alanına yönelik bu önemli çalışmalarda kaynak metinle mukayesenin görece daha sınırlı olduğu görülmektedir. Abid Nazar Mahdum’un "Ravzatü’şŞüheda ile Hadikatü’s-Sü‘eda Mukayesesinin Işığında Eski Türk Edebiyatında Tercüme Anlayışı” başlıklı tezi (Mahdum, 2001) yine uygulamaya yönelik araştırmalar arasında sayılabilir. Son dönemlerde bu türden tercüme metinlerini kaynak metinleriyle ayrıntılı bir şekilde karşılaştıran araştırmaların sayısında bir azalma olmuşsa da bu türden çalışmalara birkaç örnek vermek mümkümdür. Bahir Selçuk “Osmanlı Nesir Geleneğinde Çeviri Anlayışı, Ahlaku’s-Saltana Çevirileri Örneği”" (Selçuk, 2017) başlıklı çalışmasında bu yönde bir inceleme yapmaya gayret etmiştir. Son zamanlarda Sadık Yazar'ın bu yöndeki çalışmaları da kayda değerdir. Yazar önce Gırnatî Seyhatnâmesi'nin XVI. yüzyılda yapılan tercümesini, baştan sona kaynak metni ile ayrıntılı bir şekilde karşılaştırmış (Gırnati, 2015), daha sonra neşrettiği tercüme metinlerini de bu çalışmada benimsediği yöntemle seçilen kısımlar üzerinden tercüme açısından karşılaştırmaya devam etmiştir. Bu ilk çalışmalarında yaptığı incelemesini biraz dönüştürerek Cem Sultan'ın Cemşî̀d ü Hurşî̀d mesnevisine de uyarlayarak (Yazar, 2018) bu mesneviyi kaynak metni daha ziyade dilbilim ve belagat çerçevesinde kalarak karşılaştırmıştır. Yazar'ın çalışmalarında incelemelerin dilbilim ve belagat yönü öne çıkarken tercümelerin çeviribilim kuramlarıyla pek ilişkilendirilmediği görülmektedir. Arzu Atik de benzeri bir çalışmayı dil-içi çeviri bağlamında gerçekleştirerek XVII. yüzyıl şair ve müstensihlerinden Cevrî’nin Selîmnâme'sini dil-içi çeviri /yeniden yazım bağlamında değerlendirmiştir. (Atik, 2012) Ahmet Kartal'ın “Şebüsterî’nin Gülşen-i Râz'ı ile Elvân-1 Şirâzî’nin Gülşen-i Râz Tercümesi’nin Mukayesesi” (Kartal, 2003b) ya da “Câmî'nin Yûsuf u Züleyhâ'sı ile Hamdullâh Hamdî'nin Yûsuf u Züleyhâ'sının Mukayesesi”" başlıklı (Kartal, 2003a) birkaç çalışmasında ise tercüme metninin yukarıda künyeleri verilen çalışmalara benzer şekilde kaynak metin ile karşılaştırıldığı görülürken bu çalışmalarda tercüme usulüne dair yapılan önemli değerlendirme ve tespitlerin belli bir kuram çerçevesinde yapılmamış olduğu görülmektedir. Bu türden incelemelerde çeviribilim disiplininin birikimi ve sunduğu imkanlardan yararlanılmamış olunmasının eksikleri bariz bir şekilde hissedilmektedir.

Osmanlı döneminde üretilmiş tercüme faaliyetlerinin önemli bir kısmı, özellikle de mesnevi külliyatı gibi edebî metinler, bilimsel olarak neşredilmiştir. Bu neşirlerde kurulan metinler birbirinden pek farklı olmayan başlıklar altında incelenirken bunların tercüme yönleri çoğunlukla ihmal edilmiştir. Bu neşirlerde metinlerin tercüme ile ilişkileri ancak birkaç çalışmada irdelenmiştir. Bu yönde yapılan birkaç denemede de yapılan tercüme incelemesi daha ziyade kaynak metin ile tercüme metnin başlıklarının karşılaştırmalı bir tablo içerisinde verilmesinden öteye gidememektedir. (Bağdatlı Zihni, 2014; Yıldız, 2013)

Yurtdışında da Osmanlı çeviri tarihine yönelik birkaç çalışma yapılmıştır. Pistor-Hatam "The Art of Translation: Rewriting Persian Texts from the Seldjuks to the Ottomans" başlıklı

7 Sadık Yazar, Ahmedî’nin Cemşî̀d ü Hurşîd'ini de kaynak metni ile karşılaştırdığı bir bildiri sunmuş ise de bu bildiri henüz yayımlanmış değildir. 
yayımlanmış bildirisinde (Pistor-Hatam, 1998) yeniden yazım kavramı çerçevesinde Farsça kaynaklı edebi metinlerin tercümelerine dair bir değerlendirme yapmıştır. Yazar Farsça kaynaklı edebi metin tercümelerinin ya da tercüme ile telif sınırında yer alan kimi mesnevilerin "diller arası yeniden yazım" (inter-lingual rewritings) olarak tanımlanması gerektiğini ileri sürmektedir. Pistor-Hatam'ın bu makalesinde sorduğu bir soruya cevap vermek amaciyla makalesini kaleme aldığını ifade eden Gottfried Hagen ise 2003 yılında neşrettiği "Translations and Translators in a Multilingual Society: A Case Study of Persian-Ottoman Translations, Late 15th to Early 17th Century" başlıklı makalesinde (Hagen, 2003) Mollâ Câmî'nin (ö. 1492) Şevâhidü'n-Nübüvve'si ve Molla Miskîn'in (ö. 1547) Me'âricü'n-Nübüvve fì Medârici'lFütüvve isimli Farsça eserlerine yapılan tercümeleri Hermans, Toury, Nord, Newmark ve Munday gibi çeviribilimcilerin görüşleri ya da kuramlarıyla ilişkilendirerek incelemeye çalışmıştır. Mütercimlerin sosyal statüleri, tercümelerindeki kişisel ve toplumsal amaçları, bu amaçlarına uygun olarak çevirilerinde benimsedikleri stratejiler, kaynak metinlerin edebî özelliklerine sadakat konusundaki tercihleri gibi açılardan ele aldığ 1 tercümeleri incelemeye çalıştığg görülmektedir.

\section{Bundan Sonra Neler Yapılabilir?}

Bazı temsilci örnekleri üzerinden betimlemeye çalıştığımız Osmanlı çeviri tarihine yönelik araştırmaların henüz başlangıç düzeyinde olduğu açıkça görülmektedir. Zehra Toska'nın 2000 yılında araştırmacılara davet niteliğinde olan çalışmasından (Toska, 2000) sonra oldukça zaman geçmiş olmasına karşın Tanzimat öncesi Osmanlı tercüme geleneğine dair araştırmalarda niceliksel ya da niteliksel bir artmadan bahsetmek güçtür. İkinci bir davet olmasını umduğumuz bu çalışmada Osmanlı tercüme tarihine yönelik kimi boşluklara ve özgün konulara işaret ederek bazı tekliflerimizi aşağıda sunmak istiyoruz.

Osmanlı çeviri tarihine yönelik Batı merkezli “değer”lendirmeden uzak kalarak, Türklerin İslamiyet'i benimsemeleriyle birlikte başlayan ve XIII. yüzyıldan itibaren Anadolu sahasında Batı Türkçesiyle, yeni bir medeniyet inşasında önemli bir rol oynayan, XVII. yüzyılın ikinci yarısına kadar Arapça ve Farsça ağırlıklı olan ancak bu dönemden sonra tedricî olarak başka dillerin de kaynak alındığg yaklaşık altı yüzyıllık bir tercüme geleneğinin olduğu unutulmamalıdır. Dolayısıyla bu dönem tercüme geleneğinin kendi iç dinamikleri ve tarihî gelişimi dikkate alınarak incelemelere konu edilmesi, anakronizme düşmeden bu dönem tercüme faaliyetlerini Batı kaynaklı olup olmamasına göre “değer”li kılmak, "yok”lamak ya da ötelemekten uzak durulması gerektiği kanaatindeyiz. Bu noktada Paker ve Toska'nın da çalışmalarında üzerinde durduğu gibi, Tanzimat sonrasından başlayıp erken Cumhuriyet dönemine yayılan edebiyat tarihlerinde, Osmanlı tercüme geleneğine yönelik verilen hükümlere eleştirel bakmak gerekir.

Osmanlı dönemi tercüme faaliyetlerinin envanterini çıkarma noktasında hatırı sayılır bir mesafe kat edilmiştir. IRCICA'nın yazma eser kütüphanelerinin taranmasına dayalı Osmanlı Bilim Literatürü Tarihi dizisi tercüme eserleri de havi olup bu yönde önemli bir katkı sağlamaktadır. Farklı farklı alan ve disiplinlerde de görülebilen bu envanter çıkarma çalışmaları Sadık Yazar'ın 
“Anadolu Sahası Klasik Türk Edebiyatında Tercüme ve Şerh Geleneği” başlıklı doktora çalışmasıyla birlikte belli bir aşamaya getirilmiştir. Ancak hala bu konuda büyük bir boşluğun bulunduğu; bu sebeple dünyadaki tüm Türkçe yazma eser bulunduran kütüphanelerin taranmasına dayanan envanter çıkarma araştırmalarının devam etmesi gerektiğini düşünüyoruz. Zira bir bilimsel araştırmadan makul ve makbul düzeyde değerlendirme ve sonuçların üretilebilmesi o araştırmanın bilimsel usullerle elde edilip denetlenebilir verilere dayanmasına bağlı olduğu her akademik disiplinde geçerli hakikattir. Hal böyle iken Osmanlı tercüme geleneğine dair yorum ve değerlendirme yapabilmenin özellikle de küllî çıkarımlarda bulunabilmenin, bu gelenek çerçevesinde oluşturulan faaliyetlerin tamamı olmazsa bile hatırı sayılır temsilciliğe sahip bir döküm elde etmekle imkân dahiline girer.

$\mathrm{Bu}$ tercüme metinlerinin farklı disiplinlerdeki araştırmalara açık hale getirilecek şekilde ${ }^{8}$ bilimsel neşirlerinin yapılması gerekmektedir. Yukarıda da açıklandığı üzere; Türk dili ve edebiyatı alanında bilhassa klasik Türk edebiyatı sahasında yapılan araştırmalar sayesinde, başta manzum metinler olmak üzere Farsça kaynaklı edebî tercümelerin kahir ekseriyeti muhtelif araştırmalara konu olurken yine önemli kısmı da neşredilmiştir; ancak kelam, hadis, fıkıh, tefsir ve tasavvuf gibi dinî ilimler; sözlük, aruz, kafiye, gramer gibi dil ve edebiyat ilimleri; mantık, tarih, biyografi ve siyer gibi müşterek ilimler; hendese, astronomi, coğrafya ve musiki gibi riyâzî ilimler; tıp, kimya, simya, rüya tabiri, zooloji, mineraloji, ziraat gibi tabiî ilimler; ahlâk-âdâb ve siyaset gibi amelî ilimler sahasında yapılan ve genellikle mensur olan tercüme metinlerinin neşredilmesi konusunda çok fazla aşama katedilmiş değildir.

Osmanlı tercüme geleneğinde bulunan tercümelerin kaynak metinleri ile mukayeseli okumalara dayanan çalışmaları oldukça sınırlıdır. Halbuki ancak bu çalışmalar sayesinde; bir mütercimin tercümesinde kaynak metne ne derecede bağlı kaldığını, ne gibi eksiltme, ekleme, hülâsa etme, seçme (intihâb), derleme (istihrâc) ve nihayet taklit veya nazire yoluna başvurduğunu anlamak mümkün olacaktır. Sadece çeviribilim sahasında değil klasik Türk edebiyatı sahasındaki araştırmalarda da ciddi bir boşluk olarak devam eden bu tür çalışmaların yapılabilmesi için kaynak metnin dilini asgari düzeyde bile olsa bilmek gerekmektedir. Yer yer dilbilimsel yoğunlukta olsa da bu türden mukayeseli okumalar, Osmanlı tercüme geleneğindeki tercümelerin çeviri eleştirisi kuramları açısından da incelenmesine imkân sağlar. Hagen'in yukarıda bahsi geçen çalışması bu yönde gerçekleştirilmiş nadir çalışmalardan biri olup ele aldığı tercümeleri, mütercimlerinin sosyal statüleri, tercümelerindeki kişisel ve toplumsal amaçları, bu amaçlarına uygun olarak çevirilerinde benimsedikleri stratejiler, kaynak metinlerin edebî özelliklerine bağlılık gibi farklı açılardan incelemesini gerçekleştirirken birkaç çeviribilim kuramından da istifade etmiştir. Tunca Kortantamer (Kortantamer, 1994) gibi klasik Türk edebiyatı uzmanlarının da modern edebiyat eleştiri kuramlarının klasik Türk edebiyatı metinlerine uyarlanması bağlamında ifade ettikleri üzere, çeviri eleştirisine yönelik kuramları Osmanlı tercüme geleneğindeki metinlere uyarlamaya çalışırken bu kuramların

8 Sadece tercüme metinler değil, Osmanlı telif ve tercüme geleneğinde üretilmiş Türkçe metinlerin farklı disiplinlere açık hale getirebilmenin bu metinlerin dil-içi çeviri yoluyla günümüz Türkçesine aktarmanın da çok önemli bir işlev gördüğünü ifade etmekte fayda vardır. 
ortaya çıkış şartlarını ve ne tür metinler dikkate alınarak ihdas edildikleri unutulmamalıdır. Bu tür kuramları ne küllî olarak reddetmek ne de olduğu gibi alıp Osmanlı Türkçesi ile yazılan tercümelere uygulamak çok bir fayda sağlamaz. Bunun yerine Hagen örneğinde olduğu gibi Osmanlı edebiyat geleneğinin konumlandığı geniş ve müşterek kültürün kendine özgü özelliklerini dikkate alarak bu kuramları kullanmanın faydadan hali olmadığını düşünüyoruz.

Sadece kaynak metinleri ile değil Cem Dilçin ve Zehra Toska'nın çalışmalarında olduğu gibi aynı metne yapılan farklı tercümelerin (yeniden çeviri) birbirleriyle karşılaştırmalı olarak incelenmesi de araştırmacıları bekleyen konular arasında yer almaktadır.

Osmanlı klasik dönemi tercüme metinlerinin sebeb-i tercüme bölümlerini içeren giriş (mukaddime, dîbâce vs.) ve hâtime bölümlerinde, klasik Türk edebiyatındaki tercüme geleneğinin genel karakterini ortaya koyabilecek ve çeviribilim araştırmaları açısından hayli önemli olan "metin dışı" (para-text) veriler bulunmaktadır. Bu bölümlerde mütercimlerin; tercümelerine nasıl karar verdikleri, bunun için nasıl bir ön hazırlık yaptıkları, tercümelerinin sebeplerini, tercüme ettikleri kaynak metni neden seçtiklerini, tercümelerini hangi devlet büyüklerinin emir/istek/işaretiyle kaleme aldıkları veya kimlere ithaf ettikleri, tercümelerine hangi isimleri verdikleri gibi çeviri eleştirileri açısından önemli veriler sunabildikleri görülmektedir. Yine bu bölümlerde; tercüme faaliyetlerinin hangi sözcüklerle karşılandığı görülebildiği gibi bu bölümde verilen bilgilerden bazı tercüme kavramlarını da çıkarmak mümkündür. Örneğin günümüz çeviribilim araştırmalarında harfiyen/aynen /sözcüğü sözcüğüne/(word for word) şeklindeki ifadelerle karşılanan tercüme şeklinin bu dönemde tahte 'l-lafz olarak isimlendirildiğini görmekteyiz. Lügat anlamı bakımından "lafız altında" anlamına gelen bu birleşik sözcügün, hem tercüme hem de bazı şerhlerin girişinde kullanılışına bakılırsa bunun sözcügü sözcüğüne tercümeyi karşılamak üzere bilinçli olarak kullanıldığı anlaşılmaktadır. (Yazar, 2011, 219-222)

$\mathrm{Bu}$ giriş veya hâtime bölümlerinde tercümelerde uygulanan strateji hakkında da bilgi verildiği görülmektedir. Nergisî’nin İksîr-i Sa âdet isimli tercümesinin girişinde, bu bağlamda dile getirilen ifadeler başta Agah Sırrı Levend olmak üzere birçok araştırmacı tarafından kullanılmıştır. ${ }^{9}$ Nergisî ile aşağı yukarı aynı şeyleri söyleyen ancak ondan farklı olarak tercüme nazariyesine dair görüşlerini daha yalın ve bilimsel bir üslupla dile getiren Aydınlı İshak Hocası Ahmed Efendi'nin (ö. 1708) Akse'l-Ereb fì Tercemeti Mukaddimetü'l-Edeb adlı tercümesinin girişinde verdiği bilgiler de yakın zamanda bir çalışmaya konu olmuştur. (Yazar, 2019)

Yine bu "metin dışı" bölümlerde; kimi mütercimlerin kaynak metne sadakat noktasında da bazı bilgiler verdikleri görülmektedir. Bu anlamda kimi mütercimler kaynak metne herhangi bir eklemede bulunmadıklarını özellikle vurgularken bazıları da kaynak metne birtakım eklemelerde bulunduklarını özellikle ifade etme gereği görmüşlerdir. Öte taraftan, Osmanlı tercüme anlayışına dair önemli veriler sunan bu "metin dışı" alanlara ihtiyatla yaklaşmanın gerektiği de unutulmamalıdır. Zira mütercimlerin giriş ya da hatime bölümlerinde

9 Nergisî’nin tercümeye dair görüşleri ve bunların Arapça gelenekteki izlerine dair bir araştırma için bkz. (Demircioğlu, 2013) 
verdikleri bilgi ile yaptıkları uygulamaların yer yer örtüşmediği, kimi mütercimlerin kaynak metnin girişi ile kendi tercümelerinin girişini harmanlamaları gibi söylem ile uygulamanın uyuşmadığı durumların bulunduğuna karşı dikkatli olmak önemlidir. Osmanlı dönemi edebî metinlerinde, sebeb-i teliflerin zamanla gelenekselleșen kurgusallığı da dikkate alındığında, kaynak metinle mukayese yapılarak teyit edilmeyen söylemsel alanın araştırmacılar için bir tuzağa dönüşebileceği unutulmamalıdır.

Klasik Türk Edebiyatındaki tercüme geleneğinde hâlâ çözüme kavuşmamış telif-tercüme meselesi de -Zehra Toska ve Saliha Paker'in makaleleri bu konuya değinmektedir- üzerinde kafa yorulacak tercüme ile ilgili meselelerdendir. Hassaten Yûsuf u Züleyhâ, Leylâ vü Mecnûn, Cemşî̀ ü Hurşîd ve Hüsrev ü Şîrîn gibi çift kahramanlı aşk mesnevilerinde kaynak metne sadakat noktasında; telif ile tercüme arasındaki sınır yer yer belirsizleşir hatta bazen ortadan kalkar. Bundan dolayıdır ki bu özelliği havi kimi metinler bazı araştırmalarda tercüme olarak değerlendirilirken kimilerinde ise telif olarak telakki edilmektedir. Bu metinlerin tercüme ve telif yönlerinin ortaya çıkarılması yukarıda vurgulandığı üzere bahsi geçen metinlerin kaynak (veya öyle olduğu sanılan) metinleriyle mukayeseden geçmektedir. Sadık Yazar'ın Cem Sultan'ın Cemşîd ü Hurşî̀d mesnevisi üzerine yaptığı bu yönden bir inceleme Osmanlı tercüme geleneğinin kültüre özgü yönünü bir daha ortaya koymuş olup klasik mütercimin kaynak metnin bütünlüğüne sadakat noktasında modern çevirmenden oldukça farklı bir bakışa sahip olduğunu göstermiştir. Yine Ahmedî üzerinde sunulan bir bildiride de Ahmedî’nin kaynak metnin hikâye kısmını olduğu gibi tercüme ederek "tercüme", türlü vesilelerle tercümesine yaptığı eklemelerle de bir "telif” alanı oluşturduğu görülmüştür.

Sadık Yazar'ın da ifade ettiği üzere Osmanlı dönemi tercüme geleneğinde "tercüme" ve "şerh"in kavram ve uygulama boyutunda birbirinden bağımsız ele alınması güçtür. Bu iki kavramın tercüme ve şerh türündeki üretimlerde, sıklıkla aynı siyak u sibak içerisinde bulunmaları, bundan öte bazı durumlarda birbirlerinin yerine kullanılmaları, bu iki kavramın aynı anlam dairesinde bulunduğuna işaret etmektedir. Yine Arapça veya Farsça eserlerin açıklanıp/ açımlanıp yorumlanmasını gaye edinen Türkçe şerhlerde, tercüme olgusunun bir şekilde yer bulması; kimi tercüme faaliyetlerinde de şerh veya şerhe benzer uygulamalara rastlanması bu iki kavramı birbirine yaklaştırmaktadır. Kaynağını Türkçe metinlerin oluşturduğu şerh faaliyetleri bir tarafa bırakılacak olursa, edebî olsun edebiyat dışı olsun, Arapça ve Farsça kaynaklı Osmanlı dönemi şerh türü metinlerin aynı zamanda birer tercüme oldukları söylenebilir. Bunu şöyle açıklamak mümkündür; Türkçe dışındaki bir dil ile (Arapça, Farsça) yazılan metinler Türkçe olarak şerh edildiklerinde, kaynak metnin anlamı da bir şekilde Türkçeye aktarılır. Umumi bir biçimde, bu şerhlerde takip edilen yöntem dolayısıyla, önce şerh edilecek metindeki sözcükler teker teker dilbilimsel yönleriyle tahlil edildiği gibi, bu sözcüklerin birebir Türkçe karşılıkları yanında bağlam içinde kazandıkları anlamlarına da yer verilir. Şerh türü metinlerin tercüme olarak da değerlendirilmelerini mümkün kılan asıl sebebi, özellikle edebî şerhlerin çoğunda “"ma'nâ-yı beyt, tercüme-i beyt” gibi ifadelerle kaynak metnin sözcüğü sözcügüne veya buna yakın bir strateji ile Türkçeye aktarılmasında bulmak mümkündür. Bunların dışında, Seyyid Alî b. Seyyid Ahmed b. Seyyid Alî Hasretî’nin, Şerhu Pendi Attâr isimli şerhinde olduğu 
gibi Arapça şerhler içinde yer alan bazı manzum Türkçe tercümeler de şerh ve tercümenin birbirinden bağımsız olarak ele alınmasının pek mümkün olmadığına işaret etmektedir. Şerh türü eserlerdeki bu uygulamalar, aynı zamanda bu metinlerin birer tercüme olduklarını göstermektedir; dolayısıyla Osmanlı dönemi tarihine dair yapılacak araştırmalarda Türkçe şerh literatürünün de dikkate alınması gerekir. (Yazar, 2011, 15-19)

Osmanlı tercüme geleneği, çeviribilim disiplininde "şiir çevirisi” çerçevesinde sorunsallaştırılan tercüme faaliyetleri bakımından da zengin ve araştırmaya açık bir alandır. Bu tercümelerin kahir ekseriyeti edebî metinlerin tercümeleri iken bir kısmı da fikıh, kelam, tecvîd gibi dinî ilimler ile gramer, mantık ve tıp gibi farklı alanlarda ezberlemeyi kolaylaştırma gayesiyle yapılan manzum tercümelerdir. Gerek klasik şiirin biçimsel özellikleri gerekse de tarih boyunca çevirinin en zor alanını oluşturan şiirin üslupla ilgili özellikleri bu tür tercümelerde mütercimleri oldukça zorlamaktadır. Osmanlı çeviri tarihine yönelik araştırmalarda, mütercimlerin karşılaştıkları zorluklar, özellikle de manzum bir metnin yine manzum olarak tercümesinde önlerine çıkan engelleri aşmak için başvurdukları yollar da araştırmayı bekleyen konulardandir. ${ }^{10}$

Çeviribilimde "yeniden çeviri”" olarak nitelenen bir metnin birden fazla kez tercüme edilmesi hususu da Osmanlı tercüme tarihi araştırmaları için hayli zengin malzeme sağlamaktadır. Bazıları birbirine oldukça yakın dönemlerde bazıları ise yüzyıllara yayılan bu yeniden tercümelerle ilgili olarak önemli araştırma soruları bulunmaktadır. "Önceki/lerden haberli ya da habersiz olsun, yeniden tercümelerin sebepleri nelerdir? Bu metinlerin üretilmesinde yazma kültürünün, istinsah sürecinin etkileri olmuş mudur? Yeniden tercümelerin birbirleriyle ilişkileri nelerdir? Bunların hangileri hangi toplum kesimleri tarafından kabul görmüştür? Yeniden tercümelerin intihal olgusuyla ilişkisi var mıdır? Osmanlı tercüme geleneği yeniden tercüme olgusu ile ilgili bu ve benzeri birçok soru zemininde yapılacak araştırmalara önemli veriler sunmaktadır. Nitekim yukarıdaki sorulardan sonuncusunun kapsamına dahil edebileceğimiz şekilde, Derin Terzioğlu, İbn Teymiyye'nin Siyâsetü'ş-Şer 'iyye adlı eserinin Osmanlı dönemindeki iki tercümesini bir araştırma konusu olarak belirleyip bunlardan birinin intihal (kendine mal etme) olduğunu tespit etmiştir. (Terzioglu, 2007)

Son zamanlarda çeviribilim sahasında yeni bir kapı açarak birçok araştırmacının rağbet gösterdiği konulardan biri de "dil-içi çeviri” diye kavramsallaştırılan çeviri türüdür. Dilbilimci Roman Jakobson'un “Dilsel göstergelerin aynı dilin başka göstergeleri aracılığıyla yorumlanması” şeklinde tanımladığı (Jakobson, 1959) dil-içi çeviri, Türkiye'de daha ziyade Osmanlı Türkçesi ile yazılan metinlerin güncel Türkçeye aktarımı bağlamında "sadeleştirme”, "günümüz Türkçesine aktarma/çevirme" vb. ifadelerle hatırlanır. Bu yönüyle de bazı önemli araştırmalara konu olan dil-içi çevirinin dikkatlerden kaçan yönü ise Osmanlı tercüme geleneğinde farklı şekillerde görünüm kazanan biçimlere sahip olmasıdır. Türkiye Bilimler Akademisi’nin desteklediği “Osmanlı Döneminde Diliçi Çeviri Olgusu” başlıklı bir projesi kapsamında 2019 yılında sunduğu “Osmanlı Dönemi Yazma Kültüründe İstinsah Sürecinin Diliçi Çeviriye Evrilmesi”

10 Arapça kasidelere yapılan manzum tercümeler üzerinden bu yönde yapılan bir çalışma için bkz. (Yazar, 2014) 
başlıklı sunumunda Sadık Yazar, Osmanlı döneminde yapılan bazı yazınsal üretimlerin dil-içi çeviri bağlamında okunabileceğini ileri sürüp bu üretimleri tespit ettiği malzemeye göre şu şekilde tasnif etmiştir:

\section{Müstakil/Doğrudan Dil-içi Çeviri Faaliyetleri}

a. Lehçeler arası gerçekleşen dil-içi çeviriler

b. Aynı lehçenin farklı dönemleri arasında gerçekleşen dil-içi çeviriler

i. Nesirden nazma aktarma

ii. Nazımdan nesre aktarma

iii. Dil güncellemesi amaçlı yeniden yazımlar

iv. Islâh, telhis gibi telif türleriyle oluşan yeniden yazımlar

\section{Dolaylı Dil-içi Çeviri Faaliyetleri}

a. İnşâ türü müstakil metinlerdeki bazı manzum bölümler

b. İstinsâh sürecinde oluşan güncelleme ya da yeniden yazımlar

Bahsi geçen metinlerin dil-içi çeviri açısından incelenmesine dayanarak bu sahada yapılacak araştırmaların yukarıdaki tasnifi geliştirmesi kuvvetle muhtemeldir. Bu tür teliflerde nazma ya da nesre aktarma biçimindeki telif türleri için kullanılan "hall ü akd" gibi kültüre özgü kavramlara yönelik bir araştırma alanının da bulunduğu unutulmamalıdır. Yine tespit edilen dil-içi çeviri etkinliklerinin birbiriyle mukayese edilmesi şeklindeki incelemeler, Türkçenin Osmanlı dönemindeki gelişimine başka bir açıdan bakma imkânı sağlaması başta olmak üzere farklı bakış açıları kazandıracaktır.

Osmanlı tercüme geleneğinde özellikle dinî ve bilimsel bazı tercümelerde "istihrâc" sözcügüü ile kavramsallaştırılan bir tercüme biçimi de dikkat çekmektedir. Bu tür tercümelerde, bir konuyla ilgili olarak Arapça, Farsça veya her iki dilde yazılmış birden fazla eserden bazı bölümlerin derlenip bir araya getirildikten sonra Türkçeye aktarıldıkları ve bizzat yazarları tarafından da tercüme olarak adlandırıldıkları görülmektedir. Buna benzer bir şekilde kimi telif eserlerde, Arapça veya Farsça bir metinden (bir örnekte görebildiğimiz kadarıyla Tevrat ve İncil'den) tercüme edilmek suretiyle kullanılan ve örtük/gizli tercüme diye nitelendirilebilecek iktibaslar da üzerinde durulmayı bekleyen tercüme faaliyetleri arasında yerini almaktadır.

Tercümelerin Türk dili, edebiyatı ve biliminin gelişip tekâmüle erişmesindeki olumlu veya olumsuz katkısı da yeterince araştırılmış değildir. Çalışmamızın ilgili bölümünde üzerinde durulduğu üzere, Osmanlı tercüme geleneği hakkında ikincil kaynaklar üzerinden yapılan bazı araştırmaların tercümelerin bu işlevlerini yok saydıkları görülse de klasik Türk edebiyatı sahasında yapılan birkaç araştırma ile Saliha Paker ve Zehra Toska'nın bahsi geçen beylikler dönemine yönelik projelerinde, Anadolu sahası Türk edebiyatının erken dönemlerinde geçekleştirilen tercüme faaliyetlerinin inşa edici yönü üzerinde durulmaya çalışılmıştır. 
Mustafa İsen de bir makalesiyle bu konu üzerinde durmuş (İsen, 2003) iken Ali Fuat Bilkan ise yakın zamanda neşrettiği Osmanlı Zihniyetinin Oluşumu: Kuruluş Döneminde Telif ve Tercüme başlıklı kitabında (Bilkan, 2018) konuyu tercüme olgusunu da dahil ettiği daha geniş bir perspektifte ele almaktadır. Osmanlı dönemindeki tercüme metinler kaynak metinleri ile karşılaştırılarak incelendiğinde; müşterek İslamî kültüre ait kavramların hangi dönemlerde ve nasıl Türkçeleştirildiği veya Türkçeleştirilmeyip aynıyla alıntılandığı, İslamî edebiyat kaynaklı edebî türlerin yaygınlaşmasında bu tercümelerin ne gibi roller oynadığı, bu tercümelerin Türk dilinin söz varlığı ve gramerine yaptığı olumlu veya olumsuz etki gibi daha birçok konu hakkında yorum yapılabilecektir. Öte taraftan bahsi geçen tercümelerin etkisini sadece kuruluş dönemine hasretmek de çok doğru değildir; sadece edebiyat yönüyle konuya baktığımızda klasik Türk edebiyatındaki yönelişlerde de tercümenin önemli bir etkisi olduğu görülmektedir. Nitekim XVII. yüzyılın başından itibaren artık bir tıkanmayla yüz yüze kalan klasik edebiyat çizgisinden Sebk-i Hindî yönelişine geçişte de daha ziyade Türkçe şerhler üzerinden gerçekleşen bir tercüme etkisinden bahsetmek mümkündür.

Yukarıdaki maddenin devamı olarak dinî ilimler sahasındaki müşterek İslam medeniyeti birikiminin Osmanlı dönemine aktarılması da yeteri kadar sorunsallaştırılmış değildir. Bu noktada öncelikli olarak akla gelen ilahiyat fakültelerindeki bölümlere mensup araştırmacılar da çeviribilim bölümlerine benzer şekilde Osmanlı Türkçesi bilgisi noktasında istenen düzeyde yetkin değillerdir; ancak kanaatimizce esas sebep bu değildir. Bundan öte, yakın zamana kadar erken dönem İslam medeniyetine daha fazla rağbet gösterilmesine mukabil Osmanlı döneminin uzun süre dikkat çeken bir saha olmaması bunda önemli bir amil olmuştur. Her ne sebepten olursa olsun, bugün tefsir, hadis ${ }^{11}$, fikıh ve kelam gibi ilimlerde yapılan tercümeler ve bu tercümeler yoluyla dinî bilginin Türkçeleştirilmesi gibi konular bakir bir araştırma alanı olarak araştırmacıları beklemektedir.

Yukarıda işaret edilen boşluk ve zorluklarının yanında Osmanlı tercüme geleneğinin farklı açılardan okunmaya ve incelenmeye açık olduğunu bu dönem tercüme faaliyetlerine yöneltilebilecek şu muhtemel sorularla teyit edip geliştirmek mümkündür:

- Osmanlı dönemi tercüme geleneğinin çeviri tarihindeki yeri ve önemi nedir?

- Bu tercüme geleneğinde ne tür metinler, kimler tarafindan, nerede, nasıl ve niçin tercüme edilmiştir?

- Hangi metinler neden tercüme edilmemiştir?

- Tercüme faaliyetlerinin sebepleri nelerdir, mütercimler hangi sebeplere binaen tercüme faaliyetlerini gerçekleştirmekteydiler? Bu sebepler metin türlerine göre bir değişiklik göstermekte miydi?

- Tercüme edilecek metinlerin seçiminde nelere dikkat edilmektedir?

- Mütercimler gerçekleştirdikleri tercüme faaliyetleri için nasıl bir süreç takip ediyorlardı? Bir ön hazırlık yapıyorlar mıydı? Başta sözlükler olmak üzere ne tür yardımcı kaynaklara başvuruyorlardı?

11 Hadis sahasındaki tercümeler Türkoloji sahasındaki araştırmalar sayesinde daha fazla mesafe kat edildiği söylenebilir. 
- Osmanlı tercüme geleneğinde himayenin rolü nedir? Osmanlı toplumunda bir hami elde elde edebilmede tercümenin bir etkisinden bahsetmek mümkün müdür? ${ }^{12}$

- Mütercimlerin yetkinlikleri ne ölçüdedir; bu bağlamda tercümelerde ne tür hatalar oluşmaktadır?

- Telif tercüme çizgisinde Osmanlı müellifi/mütercimi/şairi/münşisinin tercüme olgusuna bakışı nasıldır? Bu anlamda tercüme-telif karşılaştırılması yapılmakta midir? ${ }^{13}$

- Bu tercüme geleneğinde çeviri eylemi hangi sözcük ve kavramlarla karşılanmıştır? ${ }^{14}$

- Tercüme metinleri başta olmak üzere Osmanlı edebiyat geleneğinde, daha geniş çerçevede müşterek İslam medeniyetinde, günümüze kadar yapılan araştırmalarda ortaya çıkan "tahte'l-lafz, istihrâc, terceme, nazîre, telhîs, tashîh, akd ü hall” gibi tercüme olgusu ile ilgili kültüre özgü başka kavramlar var mıdır? Bunların modern çeviribilim araştırmalarındaki kullanımına yönelik nasıl bir tutum geliştirilmelidir?

- Osmanlı Türkçesiyle kaleme alınan ve kendini telif olarak konumlandıran metinlerde tercüme nasıl bir görünüm arz etmektedir? Bu tür metinlerde sıklıkla karşılaşıldığı gibi Kur'an ayetleri, hadisler, mesel ve manzume şeklinde yer verilen iktibasların tercüme edilmeden bırakılması ne anlam taşımaktadır. Bu tür telifî üretimlerde buna benzer örtük tercüme alanları ve bunların işlevleri nelerdir?

- Tercümelerde uygulanan stratejiler, kaynak metne sadakat, ekleme, şiir çevirisi gibi konularda nasıl bir tercüme nazariyesi/kuramı gelişmiştir? $\mathrm{Bu}$ anlayışın Osmanlı öncesi İslam geleneğiyle nasıl bir ilgisi vardır? ${ }^{15}$

- Tercüme faaliyetleri sırasında kaynak metinlere eklemeler, kaynak metinlerden eksiltmeler/çıkarmalar; sansür ve başkalaştırma gibi yollarla metne müdahaleler yapılmakta mıdır? Yapılıyorsa bu ekleme ve eksiltmeler ne şekil ve düzeyde ve hangi sebepler çerçevesinde ortaya çıkmaktadır?

- Kaynak metindeki kelimelere karşılık verme biçimleri nelerdir? Metin türlerine göre bu biçimlerde bir değişiklik oluyor mu? Bu bağlamda "ödünçleme, yabancılaştırma ve yerelleştirme" gibi kavramların tezahürleri nasıl gerçekleşmektedir? Bu noktadaki tasarrufların Türkçenin gelişimine etkisi nasıl gerçekleşmiştir? Tercümelerin Türk dilinin söz varlığı ve gramerine yaptığ

12 Hagen'in çalışmasında bu sorunun cevabına yönelik işaretler bulunmaktadır. Bkz. (Hagen, 2002)

13 Menderes Coşkun'un “Klasik Türk Şiirinde Edebi Tenkit: Şairin Şaire Bakışı” başlıklı çalışmasında bu soruya cevap olarak şairlerin birbirlerini "tercüme" noktasında eleştirdikleri bazı beyitlere yer verilip bu beyitler değerlendirilmiştir. (Coşkun, 2007) Yazar da doktora tezinde bu konuya kısa bir bölüm hasretmiştir. (Yazar, 2011, 102-107) Yakın zamanda ise Ayşe Handan Konar, konuya dar bir kapsamda ama daha ayrıntılı olarak baktığı bir makale neşretmiştir. (Handan Konar, 2018)

14 Bu konuda Cemal Demircioğlu'nun çalışmalarında önemli mesafe kat edildiği görülmektedir. Doktora tezini (Demircioğlu, 2005) büyük oranda bu konuya hasreden Demircioğlu, konuyu sadece Tanzimat dönemi çevirileri bağlamında değil aynı zamanda Tanzimat öncesi tercümelerde özellikle de Anadolu sahası Türk edebiyatının erken dönemlerindeki tercüme metinleri çerçevesinde de ele almıştır. Bahsi geçen tezi dışında Demircioğlu konuyu müstakil olarak ele aldığı makaleler de neşretmiştir. Bkz. (Demircioğlu, 2009), (Demircioğlu, 2006), (Demircioğlu, 2018)

15 Bu soruya cevaben Demircoğlu ve Yazar'ın çalışmalarına hareket noktası olarak müracaat edilebilir. Bk. (Demircioğlu, 2013), (Yazar, 2019) 
olumlu veya olumsuz etkiler nelerdir? Türkçenin söz diziminde bu tercümelerin etkisi olmuş mudur?

- Tercümelerin Türk dili, edebiyatı ve biliminin gelişip tekâmüle erişmesindeki olumlu veya olumsuz katkısı nedir? Bu bağlamda müşterek İslamî edebiyat dizgesinde yer alan edebî türlerin yaygınlaşmasında bu tercümelerin ne gibi rolü olmuştur? Mesnevi türü bağlamında yaygın olarak söz konusu edilen bu etki gazel ve kaside gibi türlerde nasıl gerçekleşmiştir?

- Tercüme edilen metinlerin biçimsel/yapısal özelliklerine (manzum, mensur, manzum-mensur, aruz, kafiye ve nazım biçimleri gibi) bağl1lık nasıl bir görünüm arz etmektedir? Biçimsel özelliklerin korunması veya terk edilmesinde aynı kültürel dizge içerisinde bulunmanın etkisi var mıdır?

- Şiir olsun nazım olsun manzum tercümelerde; kaynak metinlerin şiirselliği ve beliğ yönü erek metne ne düzeyde ve nasıl aktarılmaktadır?

- Osmanlı tercüme geleneğinde Kur'an başta olmak üzere kutsal metinlerin çevirileri nasıl bir seyir takip etmektedir? Kitab-1 Mukaddes Osmanlı döneminde tercüme edilmiş midir? ${ }^{16}$ Kur'an'ın tercüme edilmesine bakış nasıldır? Fıkhî boyutu gelişmiş midir?

- Berrin Aksoy’un makalesinde ifade edildiği üzere (Aksoy, 2005) Osmanlı dönemindeki tercümeler, belli bir program ve sistematikten uzak "örgütsüz" bir şekilde, "bütünüyle kişisel girişimler neticesinde" mi yapıldı?

- Sözlü çeviri dolayısıyla kurumsallaşmayla ilişkilendirilen Osmanlı tercüme geleneğinde yazılı çeviri bağlamında bir kurumsallıktan bahsedilemez mi? Bu noktada medrese-tercüme ilişkisinden bahsetmek, daha ileri bir yorumla medreseleri "tercümenin arka bahçesi” olarak görmek mümkün müdür?

Başka ifade ve şekillerde, geliştirilerek ve artırılarak sorulabilecek bu sorular, aşağıda asgari düzeyde yeterliklerinden bahsedilecek araştırmacılar için Osmanlı tercüme geleneği bağlamında önemli boşluklara ve meselelere işaret etmektedir.

\section{SONUÇ YERINE: BU ÇALIŞMALAR KIMLER VEYA HANGİ DISİPLINLER TARAFINDAN YAPILABILIIR/YAPILMALIDIR?}

Evvelemirde Osmanlı dönemindeki tercüme faaliyetleriyle tespit, tahlil ve tenkit bağlamında muhatap olacak araştırmacılarda asgari düzeyde şu yeterliklerden bahsetmek mümkündür:

a. Bahsi geçen dönemde üretilen tercümelerin dili ile bu tercümelere kaynaklık eden metinlerin yazıldıkları dilleri bilmek.

b. Çeviri eleştirisine dair geliştirilen kuramları okumak/anlamak/özümsemek.

c. Edebî tercümeler söz konusu olduğunda ise hem kaynak hem de erek metnin üretildiği dilin edebî geleneği hakkında asgari düzeyde bilgi sahibi olmak gerekir.

16 Bu soruya giriş mahiyetinde cevap olmak üzere Sadık Yazar, Tanzimat öncesi dönemdeki İncil tercümelerine dair bir bildiri sunmuştur. (Yazar, 2010) Ancak bu konuda Bruce G. Privratsky "A History of Turkish Bible Translations" başlıklı Türkçeye tercüme edilmiş hacimli çalışmasıyla çok büyük bir boşluğu doldurmuştur. Bkz. https://historyofturkishbible.wordpress.com/ 
Osmanlı dönemi tercüme faaliyetleri, her ne kadar daha dolaylı olarak farklı disiplinler tarafından muhtelif sebeplerle ele alınabilirlerse de formasyonları ve temel araştırma alanları dolayısıyla bunlara doğrudan muhatap olması beklenen araştırmacılar; çeviribilim, Türkoloji (klasik Türk edebiyatı, yeni Türk dili, yeni Türk edebiyatı) ve Şarkiyat (Doğu dilleri ve edebiyatları) gibi bölümlerdeki araştırmacılardır.

Son dönemde sayıları artan çeviribilim bölümleri doğrudan bu metinlere muhatap olmasına karşın; hâlihazırdaki altyapısı, formasyonu, müfredatı ve ilgisi göz önüne alınırsa kısa vadede bu tercüme metinleri üzerinde çalışmalar yapmalarını beklemek pek de gerçekçi olmayan bir beklenti gibi durmaktadır. Zira bu bölümlerde görev yapan araştırmacıların önünde, kendilerini bu alana sevk etmeyi neredeyse imkânsız hale getiren bazı güçlükler bulunmaktadır. Bunların başında da bu metinleri okuyup anlamalarını sağlayacak Osmanlı Türkçesi bilgisinin eksikliğidir. Ancak Boğaziçi Üniversitesi Çeviribilim Bölümünün yaptığ1 ve semeresini de yavaş yavaş almaya başladığı gibi; Türk dili ve edebiyatı veya Doğu dilleri ve edebiyatları bölümleri ile yapılacak olan disiplinlerarası çalışmalar sayesinde çeviribilim araştırmacılarının da bu alana yönelmesi mümkün olabilir. Yine Türk dili ve edebiyatı çıkışlı öğrencileri lisansüstü programlara kabul edip çeviribilim formasyonlarını verdikten sonra onları klasik Türk edebiyatındaki İslamî kaynaklı tercümelere yönlendirmek suretiyle de bu, kısmen de olsa başarılabilir. Tersi durum da yani çeviribilim çıkışlı öğrencileri Türk dili ve edebiyatı ya da Doğu dilleri ve edebiyatları bölümlerine yönlendirmek mümkün bir yol gibi görünse de bu bölümlerin asgari düzeydeki yeterliklerini edinmek zaman alacağından rağbet görmeyen bir yol olarak telakki edilebilir.

Neredeyse her üniversitede bulunan Türk dili ve edebiyatı bölümleri, özellikle de bu bölümlerin klasik Türk edebiyatı ve yeni Türk dili bilim dallarında görev yapan araştırmacılar; sahip oldukları donanım, bu tercümelerin de üretildiği dönemdeki eserlerin kendilerinin temel araştırma konuları arasında yer alması ve bahsi geçen bu tercüme metinlerini okuyup anlamada nispeten daha yetkin olmaları dolayısıyla yukarıda sıralanan araştırma sahalarına yönelmeleri daha fazla beklenen araştırmacılar olarak karşımıza çıkmaktadır. Nitekim mevcut çalışmaların çoğu da bu araştırmacılar tarafından yapılmıştır. Ancak yukarıda da ifade edildiği üzere; bu bölümlerde yapılan tercümeyle ilgili araştırmaların daha ziyade bibliyografik bir mahiyette olduğu ve yapılan çalışmaların büyük bir bölümünün de manzum metinler üzerine yoğunlaştığı görülmektedir. Öte taraftan bu araştırmacıların, bahsi geçen tercümelerin kaynak dillerini karşılaştırmalı okumalar yapacak düzeyde bilmemeleri ve çeviribilim kuramlarına pek aşina olmamaları, daha nitelikli araştırmalar yapmaları noktasında önlerinde birer engel olarak ortada durmaktadır. Aynı durum bilim-felsefe tarihi, Doğu dilleri ve edebiyatları bölümleri ile ilahiyat fakültelerindeki bazı bölüm mensubu araştırmacılar için de geçerlidir.

Tanzimat öncesi Arapça ve Farsça kaynaklı Osmanlı tercüme geleneğine dair araştırmaların genel bir görünümünün verilip bu alandaki boşluk ve zorluklara işaret edilmesinin amaçlandığı bu makalede, Osmanlı dönemi tercüme faaliyetlerine yönelik çalışmalarda çok az mesafe katedildiği bariz bir sonuç olarak ortaya çıkmıştır. Çeviribilim sahası dışındaki disiplinlerde 
yapılan araştırmaların, Osmanlı tercüme literatürünün ortaya çıkarılmasında önemli katkıları olduğu görülmüştür; ancak bu araştırmaların genel olarak betimleyici bir düzeyde kalıp tercüme metinlerinin kaynak metinleri ile mukayese edildiği, çeviri eleştirisi kuramları çerçevesinde değerlendirilip dilbilimsel, toplumsal ve kültürel işlevlerinin ortaya çıkarılmaya çalışıldığı tahlilî çalışmalara evrildiğini söylemek güçtür. Öte taraftan çeviribilim sahasında, Osmanlı tercüme geleneğine yönelik yapılan araştırmaların ise çok sınırlı bir muhitte (Boğaziçi Üniversitesi Çeviribilim Bölümü) gerçekleştirildiği, bu sınırlı muhitte yapılan araştırmaların da yine ekseriyetle Tanzimat sonrası Batı kaynaklı çevirilere odaklandığı görülmektedir. Böyle bir görünümün ortaya çıkmasında, Osmanlı dönemi tercüme geleneğinin çok yönlü donanımlara sahip olmayı zorlayan kültüre ve zamana özgü yapısının çok etkili olduğu görülmüştür. Bu zorluğu aşmak için farklı yollar önerilebilse de Boğaziçi Üniversitesi Çeviribilim Bölümünün sonuç veren tecrübesini örnek alarak çeviribilim, Türkoloji ve bilim-felsefe tarihi gibi disiplinler arasında işbirliği yapmanın en kısa vadede en etkili yol olduğu sonucuna varılmıştır.

Hakem Değerlendirmesi: Dış bağımsız.

Çıkar Çatışması: Yazar çıkar çatışması bildirmemiştir.

Finansal Destek: Yazar bu çalışma için finansal destek almadığını beyan etmiştir.

Peer-review: Externally peer-reviewed.

Conflict of Interest: The author has no conflict of interest to declare.

Grant Support: The author declared that this study has received no financial support.

\section{KAYNAKÇA/REFERENCES}

Abd el-Maksoud, B. S. M. (2004). Leylâ ile Mecnun Mesnevisinin Arap, Fars ve Türk Edebiyatı'nda Ele Alınış Biçimi ve Larendeli Hamdi ’nin Eseri. Yayımlanmamış doktora tezi. İstanbul Üniversitesi, İstanbul.

Aksoy, B. (2005). Translation Activities in the Ottoman Empire. Meta, 50(3), 949-956.

Atik, A. (2012). Bir Hulasa Denemesi: Cevrî ve Selîmnâme’si. Divan Edebiyatı Araştırmaları Dergisi, $8,21-21$.

Bağdatlı Zihni. (2014). Yusuf u Züleyha (A. Doğan, Ed.). İstanbul: Kesit Yayınları.

Balcı, S. (2006). Osmanlı Döneminde Tercümanlık ve Bab-ı Ali Tercüme Odası. Yayımlanmamış doktora tezi, Ankara Üniversitesi, Ankara.

Balcı, S. (2013). Babıali Tercüme Odası. İstanbul: Libra Kitapçılık ve Yayıncılık.

Bilkan, A. F. (2018). Osmanlı Zihniyetinin Oluşumu Kuruluş Döneminde Telif ve Tercüme. İstanbul: İletişim Yayınları.

Coşkun, M. (2007). Klasik Türk Şiirinde Edebi Tenkit Şairin Şaire Bakışı. Ankara: Akçağ Yayınları.

Demircioğlu, C. (2005). From Discourse to Practice: Rethinking “Translation” (Terceme) and Related Practices of Text Production in the Late Ottoman Literary Tradition. Yayımlanmamış doktora tezi, Boğaziçi Üniversitesi, İstanbul.

Demircioğlu, C. (2006). Turkish Terms/Concepts for Translation from the Pre-Ottoman to Ottoman Periods: An Overview (1). Iranian Journal of Translation Studies, 4(15), 11-32. 
Demircioğlu, C. (2008). Tuzaklar ve 'Kapılar’: Osmanlıda Çeviri Tarihini Araştırırken Nereden Başlamalı?” [Traps and 'Doors': Where to Start in Studying Ottoman Translation History]. Asalet Erten (ed.), Uluslararası Çeviribilim Konferansı Bildirileri, Çeviribilimde Yeni Ufuklar, 11-12 Mayıs 2006, Proceedings of The International Translation Studies Conference, içinde (ss. 237-249). Ankara: Bizim Büro Yayıncılık.

Demircioğlu, C. (2009). 19. Yüzyıl Sonu Türk Edebiyatında ‘Tercüme Kavramı. Journal of Turkish Studies (Türklük Bilgisi Araştırmaları), Kaf Dă̆ının Ötesine Varmak, Günay Kut Armă̆anı, II(27), 13-31.

Demircioğlu, C. (2013). El-Cahız'dan Manastırlı Memet Rıfat'a: Arap Çeviri Kuramcıları ile Osmanlı Mütercimleri Arasındaki Bağlantılar. Turkish Studies, 8(13), 739-759.

Demircioğlu, C. (2016). Çeviribilimde Tarih ve Tarihyazımı. İstanbul: Boğaziçi Üniversitesi Yayınevi.

Demircioğlu, C. (2018). 19. Yüzyıl Osmanlı Toplumunda “Çeviri”ye Yüklenen İşlevler. Journal of Turkish Studies (Türklük Bilgisi Araştırmaları), Saliha Paker Armă̆anı, 49, 179-202.

Dilçin, C. (1993). Mantıkut-Tayr'ın Manzum Çevirileri Üzerine Bir Karş1laştırma. Ankara Üniversitesi Dil ve Tarih-Coğrafya Fakültesi Dergisi, XXXVI(1-2), 35-52.

Fazlıoğlu, İ. (2003). Osmanlı Döneminde "Bilim” Alanındaki Türkçe Telif ve Tercüme Eserlerin Türkçe Oluş Nedenleri ve Bu Eserlerin Dil Bilincinin Oluşmasındaki Yeri ve Önemi. Kutadgubilig: Felsefe - Bilim Araştırmaları, 3, 151-184.

Girnati, E. M. el. (2015). Tercüme-i Tuhfetü'l-Elbab ve Nuhbetü'l-A'cab/ Gırnati Seyahatnamesi (S. Yazar, Ed.). İstanbul: Büyüyenay.

Gottfried, H. (2002). Some Consideretions About the Terğüme-i Darîr based on manuscripts in German Libraries. Journal of Turkish Studies /Türklük Bilgisi Araştırmalarl, 26, 323-337.

Güleç, İ. (2008). Türk Edebiyatında Mesnevi Tercüme ve Şerhleri. İstanbul: Pan Yayıncılık.

Günergun, F. (2012). Osmanlı'nın Avrupa Bilimi ile Münasebetleri 16-17. yy.'da Türkçe Çeviriler. (P. Burke, R. Po-chia Hsia, Ed.), Erken Modern Avrupa'da Kültürel Çeviri. içinde (ss. 225-248). İstanbul: İş Bankası Yayınları.

Hagen, G. (2003). Translations and Translators in a Multilingual Society: A Case Study of Persian-Ottoman Translations, Late Fifteenth to Early Seventeenth Century. Eurasian Studies, 2(1), 95-134.

Handan Konar, Ayşe. (2018). “O1 Dil-Ârâma geyür Rûmî Kabâ”" “ ‘İdüp Sihrile Tecdîd””: 15. Ve 16. Yüzyıl Mesnevilerinde Tercüme Üzerine Söylenenler. Journal of Turkish Studies (Türklük Bilgisi Araştırmaları), Saliha Paker Armağanı, 49, 243-256.

İsen, M. (2003). Türkçe’nin Yazı Dili Oluşumunda Çevirilerin Rolü. B. Yediyıldız (ed.). Dil, Kültür ve Çağdaşlaşma. İçinde (ss. 137-152). Ankara: Hacettepe Üniversitesi Yayınları.

Jakobson, R. (1959). On linguistic aspects of translation. On translation, 3, 30-39.

Karahan, A. (1991). İslam Türk Edebiyatında Kırk Hadis: Toplama, Tercüme ve Şerhleri (2. bs). Ankara: Diyanet İşleri Başkanlığı yayınları.

Kartal, A. (2001). Sa’dî-i Şîrâzî’nin Gülistân İsimli Eserinin Türkçe Tercümeleri. Bilig, 16, 99-126.

Kartal, A. (2003a). Câmî’nin Yûsuf u Züleyhâ'sı ile Hamdullâh Hamdî’nin Yûsuf u Züleyhâ'sının Mukayesesi. Diriözler Armă̆anı. İçinde (ss. 93-139). Ankara: Bizim Büro Basımevi.

Kartal, A. (2003b). Kartal, Ahmet, “Şebüsterî’nin Gülşen-i Râz’1 ile Elvân-1 Şirâzî’nin Gülşen-i Râz Tercümesi'nin Mukayesesi. Türk Dili ve Edebiyatı Makaleleri, 3, 121-176.

Kayaoğlu, T. (1998). Türkiye’de Tercüme Müesseseleri. İstanbul: Kitabevi.

Kerman, Z. (1978). 1862-1910 Yılları Arasında Victor Hugo'dan Türkçeye Yapılan Tercümeler Üzerinde Bir Araştırma. İstanbul: İstanbul Üniversitesi Edebiyat Fakültesi Yayınları. 
Koç, H. (2004). Cultural Repertoire as a Network of Translated Texts: The New Literature After the Tanzimat Period (1830-1870). Yayımlanmamış yüksek lisans tezi, Boğaziçi Üniversitesi, İstanbul.

Kortantamer, T. (1994). Teori Zemininde Metin Şerhi Meselesi. Ege Üniversitesi Türk Dili ve Edebiyatı Araştırmaları Dergisi, VIII, 1-10.

Mahdum, A. N. (2001). Ravzatü'ş-şühedâ ile Hadîkatü's-sü'edâ Mukayesesinin Işığında Eski Türk Edebiyatında Tercüme Anlayışı. Yayımlanmamış doktora tezi, İstanbul Üniversitesi, İstanbul.

Meral, A. (2013). A Survey of Translation Activity in the Ottoman Empire. Osmanlı Araştırmalarl, 42, 105-155.

Özmen, C. (2016). Osmanlı İmparatorluğu’nda Bilimi Çevirmek: Osmanlı Bilim Repertuarlarında “Değişim Özneleri” Olarak Mütercim-Hocalar (1789-1839). Osmanlı Araştırmaları, 48, 143-170.

Öztoprak, N. (1993). Klâsik Türk Edebiyatında Manzum Yüz Hadisler. Yayımlanmamış doktora tezi, Marmara Üniversitesi, İstanbul.

Paker, S. (2002). Translation as Terceme and Nazire: Culture-bound Concepts and their Implications for a Conceptual Framework for Research on Ottoman Translation History. Crosscultural Transgressions, Research Models in Translation Studies II Historical and Ideological Issues. İçinde (ss. 120-143). Amsterdam: St Jerome Publishing.

Paker, S. (2004). Türkiye Odaklı Çeviri Tarihi Araştırmaları, Kültürel Hafıza, Unutuş ve Hatırlayış İlişkileri. Journal of Turkish Studies (Türklük Bilgisi Araştırmaları), Günay Kut Armă̆anı, III(28), 275-284.

Paker, S. (2007). Influence-Imitation-Translation OR Translation-Imitation-Influence? A Problematic Interrelationship in Mehmed Fuad Köprülü's Literary-Historical Discourse. A. P. Christidis (Ed.), Language, Society, History: The Balkans içinde (ss. 265-277). Thessaloniki: Centre for Greek Language.

Paker, S. (2009). Tercüme ve Nazire olarak Çeviri: Kültüre Bağlı Kavramlar. Journal of Turkish Studies / Türklük Bilgisi Araştırmaları (Cem Dilçin Armă̆anı), 33(2), 89-110.

Paker, S. (2014). Tercüme, Telif ve Özgünlük Meselesi. Eski Türk Edebiyatı Çalışmaları IX Metnin Halleri: Osmanlı'da Telif, Tercüme ve Şerh içinde (ss. 37-71). İstanbul: Klasik Yayınları.

Pistor-Hatam, A. (1998). The Art of Translation: Rewriting Persian Texts from the Seldjuks to the Ottomans. Archiv Orientalni : Quarterly Journal of African and Asian Studies, VIII. cilt [Essays on Ottoman Civilization : Proceedings of the XIIth Congress of the Comité International d'Etudes Pré-Ottomanes et Ottomanes] içinde (ss. 305-316). Praha: Academy of Sciences of the Czech Republic.

Selçuk, B. (2017). Osmanlı Nesir Geleneğinde Çeviri Anlayışı, Ahlaku's-Saltana Çevirileri Örneği. Osmanlı Nesrinin Dili içinde (ss. 339-363). Ankara: Atatürk Kültür Merkezi Yayını.

Sucu, N. (2006). Eski Türk Edebiyatında Tercüme Geleneği. Selçuk Üniversitesi Türkiyat Araştırmaları Dergisi, 19, 125-148.

Şahin, E. S. (1997). Kasîde-i Bürde’nin Türkçe Şerh ve Tercümeleri. Yayımlanmamış yüksek lisans tezi, Gazi Üniversitesi, Ankara.

Şeşen, R. (1991). Onbeşinci Yüzyılda Türkçeye Tercümeler. Mimar Sinan Üniversitesi Fen/Edebiyat Fakültesi Dergisi, 1, 213-233.

Şeşen, R. (2004). Lale Devrinde Yenileşme Hareketleri ve Tercüme Edilen Eserler. Journal of Turkish Studies = Türklük Bilgisi Araştırmalarl, XXVIII(2), 47-57on.

Terzioglu, D. (2007). Bir Tercüme ve Bir İntihal Vakası: Ya da İbn Teymiyye'nin Siyasetü’ş-Şeriyyesini Osmanlıcaya Kimler Nasıl Aktardı? Journal of Turkish Studies (Türklük Bilgisi Araştırmaları),Şinasi Tekin Armă̆anı, II(31), 247-275.

Toska, Z. (2000). İleriye Yönelik Araştırmalarla İlgili Olarak Eski Türk Edebiyatı Sahasında Yazılmış Olan Çeviri Metinleri Değerlendirmelerde İzlenecek Yöntemler Ne Olmalıdır. Journal of Turkish Studies (Türklük Bilgisi Araştırmalarl), XXIV,(1), 291-306. 
Toska, Z. (2002). Evaluative Approaches to Translated Ottoman Turkish Literature in Future Research. Saliha Paker (ed.), Translations: (re)shaping of literature and culture. içinde (ss. 58-76). İstanbul: Boğaziçi Üniversitesi Yayınları.

Toska, Z., \& Kuran Burçaoğlu, N. (2010). Ferideddin-i Attar'ın Mantıku’t Tayr adlı Yapıtı'nın 14, 16, 17 ve 20. Yüzyıllarda Yapılmış Türkçe Yeniden Yazımları. Çeviriye Bilimsel Yaklaşımlar. İçinde (ss.108122). İstanbul: Multilingual.

Toska, Z., \& Paker, S. (1997). A Call for Descriptive Translation Studies on the Turkish Tradition of Rewrites. M. Snell-Hornby, Z. Jettmarova, K. Kaindl (ed.). Translation as Intercultural Communication. İçinde (ss. 79-88). Amsterdam: John Benjamin Publishing Company.

Yasa, Ş. Alpaslan. (2003). La Traduction Chez les Turcs Anciens et sous la Dynastie Abbasside. Hacettepe Üniversitesi Edebiyat Fakültesi Dergisi, 20(2), 203-223.

Yazar, S. (2010). New Testament Translations On The Ottoman Period (XIII-XIX Century). 32th Conferance of Melcom.Yayımlanmamış Bildiri. Cordoba.

Yazar, S. (2011). Anadolu Sahası Klâsik Türk Edebiyatında Tercüme ve Şerh Geleneği. Yayımlanmamış Doktora Tezi, İstanbul Üniversitesi, İstanbul.

Yazar, S. (2014). Osmanlı Dönemi Şiir Tercümesinde Karşılaşılan Biçimsel (nazım biçimi, aruz ve kafiye) Zorluklar. Hatice Aynur-Müjgân Çakır-Hanife Koncu-Selim S. Kuru-Ali Emre Özyıldırım (hazırlayanlar), Metnin Hâlleri: Osmanlı'da Telif, Tercüme ve Şerh içinde (ss. 248-293), İstanbul: Klasik Yayınları.

Yazar, S. (2018). Bir Tercüme Metni Olarak Cem Sultân’ın Cemşîd ü Hurşîd Mesnevisine Dair Bazı Dikkatler, B. Kemikli, O. Kocatürk (Ed.), Cem Sultan ve Dönemi içinde (ss. 171-182). Bursa: Osmangazi Belediyesi Yayınları.

Yazar, S. (2019). Nergisî (ö. 10441636) ve İshak Hocası Ahmed Efendi (ö. 11201708) Örnekleminde Osmanlı'da Tercüme Nazariyesi. M. Kaçar, Ö. Bozkurt (ed.). Fuat Sezgin Anısına-Bilim Tarihine Yeni Bakışlar içinde (ss. 245-261), Mardin: Mardin Artuklu Üniversitesi Yayınları.

Yıldız, A. (2013). Çakeri Yusuf u Züleyhâ. Ankara: Hitabevi. 